\title{
A PERIOD OF THE REPUBLIC OF EDUCATIONAL INSTITUTIONS TO EXAMPLE: KÜTAHYA COMMUNITY HOME AND ACTIVITIES (1932-1937)
}

\author{
HAVANUR ŞAHIN * \\ * Sakarya Üniversitesi, Dumlupınar Üniversitesi \\ E-mail: nursahin@comu.edu.tr
}

Copyright (C) 2015 HAVANUR ŞAHIN. This is an open access article distributed under the Eurasian Academy of Sciences License, which permits unrestricted use, distribution, and reproduction in any medium, provided the original work is properly cited.

\begin{abstract}
During the period that they were active (1932-1951), people's houses, which can be considered as institutions for public education in its broadest sense, strived for spreading the Turkish culture, strengthening the roots of the Turkish revolution, and promoting national unity. These institutions, which were a place for the intelligentsia and the public to get closer to each other, also played an important role in the realization of Turkish modernization. The People's House in Kutahya went into action on June 24, 1932 with its divisions of Language, History and Literature, Library and Publication, Representation, Fine Arts, Public Training Centres and Courses, Village Activities, and Social Aid. It is seen that, in that period, people from different occupational groups, Kutahya's well-known faces and a lot of educators were members of the People's House. It is understood from the high level of participation that the activities of the People's House in Kutahya were city-wide. Especially activities such as conferences, concerts, exhibitions drew a great deal of people's attention. In this respect, it can be said that the People's House in Kutahya made significant contributions in raising the educational and cultural level of the local people.
\end{abstract}

Keywords: Community Home, Modernizm, Community Home Publishing, Activity

\section{Cumhuriyet Dönemi Eğitim Kurumlarına Bir Örnek : Kütahya Halkevi ve Faaliyetleri (1932-1937)}

\section{ÖZET}

Geniş anlamıyla birer halk eğitimi kuruluşu olan halkevleri, faaliyet gösterdiği dönemde (1932-1951) Türk kültürünü yaymaya, Türk inkılâbını kökleştirmeye ve milli birliği sağlamaya çalışmıştır. Aydınlar ile halkın kaynaşma yeri olan bu kuruluşlar aynı zamanda Türk modernizminin gerçekleşmesinde de önemli rol oynamışlardır.24 Haziran 1932 yılında kurulan Kütahya Halkevi Dil, Tarih ve Edebiyat, Kütüphane ve Yayın, Temsil, Güzel Sanatlar, Halk Dershaneleri ve Kurslar, Köycülük, Sosyal Yardım şubeleriyle faaliyete başlamıştır. Halkevine o dönemde çeşitli meslek gruplarına mensup bazı kişilerin, Kütahya'nın tanınmış simalarının ve pek çok eğitimcinin üye olduğu görülmektedir. Kütahya Halkevi faaliyetlerinin bu ilin genelini kapsadığ faaliyetlere olan katılımlardan anlaşılmaktadır. Özellikle konferans, konser, gösterit gibi faaliyetler halkın yoğun ilgisini çekmiştir. Bu bağlamda Kütahya Halkevi'nin yöre halkının eğitim ve kültür seviyesinin yükselmesinde kayda değer katkılar sağladığı söylenebilir. 
Anahtar Kelimeler: Halkevi, Modernizm, Eğitim, Halkevi Neşriyatı, Faaliyet

\section{Giriş}

Cumhuriyetin ilanından sonra halka inkılâpları anlatmak ve benimsetmek amacıyla açılan halkevleri, devlet ve halk arasındaki iletişimin sağlanması görevini yürütmüştür. Kısa zamanda yurdun dört bir yanını saran bu kurumlar devlet destekli bir eğitim seferberliğine girişmiş, bulunduğu yerin kültür merkezi durumuna gelmiştir. Halkevleri tüzüğü gereği, yapılan faaliyetlerin titizlikle kayıt altına alınması, raporlar halinde genel merkeze sunulması, halkevleri hakkında yapılan çalışmaların temelini oluşturan arşiv malzemesinin oluşmasını da beraberinde getirmiştir. Faaliyet gösterdikleri 1932-1951 yılları arasında Türk kültürünü yaymaya, Türk inkılâbını kökleştirmeye ve milli birliği sağlamaya çalışan Halkevleri, ilk kez 1932'de 12 ilde birden açılmıştır. Şubeleri ve faaliyetleri halkevleri tüzüğüyle belirlenen bu kurumlar bir dönemin sosyal ve kültürel yaşamına önemli katkılar sağlamıştır. Halkevlerinin faaliyetlerinin kayıt altına alınması ve raporlar halinde sunulması, bu kurumlar ile ilgili önemli bir arşivin doğmasını beraberinde getirmiştir. $O$ dönemin şartları gereği çoğu el yazısıyla kaleme alınan bu belgelerin özünü; 1. ve 2. altı ayda hazırlanan raporlar, halkevi üyeleri sicil tutanakları, CHP'ye gönderilen yazılar, karşılıklı yazışmalar ve halkevleri arasında özellikle sinema filmlerinin gösterilmesi üzerine, bu filmlerin gönderildiği veya teslim alındığına dair yazışmalar oluşturmaktadır. Yerel tarih araştırmalarında özellikle Cumhuriyetin ilk yıllarına ait, bulunduğu yerle ilgili bilgiler içermesi, bu arşiv belgelerini değerli kılmaktadır. Bu bağlamda Kütahya Halkevi yıllık faaliyet raporları esas alınarak bu kurumun şehrin eğitim ve kültür hayatındaki rolü önem arzetmektedir.

1932 y1lı Haziranında açılan Kütahya Halkevi’nin konu edinildiği bu çalışma, bu kurumun 1937 yılına kadarki faaliyetlerini aydınlatmayı amaçlamaktadır. Araştırmanın temelini oluşturan halkevi çalışma raporlarının sınırlılı̆̆ı, araştırmanın kapsamını da daraltmıştır. 1932, 1933, 1935, 1937, 1938 ve 1941 yılına ait sadece bir şubenin faaliyet raporlarının varlığı, araştırmanın da bu tarihlerle sınırlı kalmasına neden olmuştur. Kütahya Halkevi'nin 1948'e kadar aktif olduğunu yazışma sayılabilecek bir belge ile öğrenmekteyiz. Buna rağmen; 1937 yılından sonra birkaç şubenin dışında faaliyet raporlarına ulaşılamaması, araştırmanın 5 yıllık süredeki faaliyetlerinin ele alınmasını zorunlu kılmıştır.

Kütahya Halkevinin teşkilat yapısı başlığı altında Kütahya Halkevi başkanları, bazı senelere ait idari kadrolar, bir dönemin tanınmış simaları olan halkevinin kurucu üyelerinden bahsedilmiştir. Kütahya Halkevi’nin kuruluşu, teşkilat yapısı ve faaliyetleri, 1933, 1935, 1937, 1938 ve 1941 yıllarına ait faaliyet raporları esas alınarak incelenmiş ve halkevinin önemli faaliyetleri arasında olan yayınlar üzerinde durulmuştur. Halkevinin çıkardığı, kitap ve broşürlere yer verilerek eserlerin kısa bir özeti yapılmıştır. Kütahya Halkevi'nden çıkan süreli bir yayın olmadığından bu bölüm eserlerle ve halkevi hakkında Vilayet Gazetesinde çıkan yazılarla sınırlı kalmıştır.

Araştırmada, arşiv çalışması ve kaynak taraması yöntemleri kullanılarak, muhteva çözümlemesine gidilmiştir. Dönemin şartları gereği, çoğu el yazısıyla kaleme alınan çalışma raporlarını elde etmek için Cumhuriyet Halk Partisi Genel Sekreterliği, Halkevi Başkanlığı 
Arşivi ve Başbakanlık Devlet Arşivleri Genel Müdürlüğü Cumhuriyet Arşivi’nden yararlanılmıştır. Aynı zamanda Kütahya yerel basını da gözden geçirilmiş ve Kütahya Vilayet Gazetesi taranmıştır. Toplanan istatistikî verilerin analizi yapılmış, sayısal verilerin derlenip tablolaştırılması sağlanmıştır. Böylece Kütahya Halkevi'nin 1932-1937 yılları arasındaki faaliyetleri hakkında belgeler 1şı̆̆ında bilgiler verilerek, değerlendirmeler yapılmıştır.

\section{o 1. Kütahya Halkevi’nin Açılışı ve Teşkilat Yapısı}

24 Haziran 1932'de açılan Kütahya Halkevi'nin açılışına halkın büyük bir kısmı katılmış, merasimde vilayet matbaası sahibi Halil Kadri Bey, ağır ceza reisi Sadık Bey ve matbaa müdürü Nuri Bey konuşma yapmışlardır. Merasimde halkevinin açılış maksadı izah edilmiş, muallim Asım bey "Halkevleri Açılırken” adlı şiiri okumuştur. Kuruluşla ilgili en önemli belge açılışın 1. yıl dönümü münasebetiyle yayınlanan "Ülkü Yolunda Kütahya Halkevi " adlı eserdir. Eserde Kütahya Halkevi’nin kuruluşundaki manzara, şubelerin açılış tarihi ve 1 yıl içindeki faaliyetleriyle anlatılmıştır (Ü.Y.K.H., 1933: 1).

Kütahya Halkevi'nin dil, tarih ve edebiyat, güzel sanatlar, temsil, spor, sosyal yardım, halk dershaneleri ve kurslar, kütüphane ve yayın, köycülük olmak üzere 9 şubesi açılmıştır (CHPG.S., 1932-1935: 74-75). “Ülkü Yolunda Kütahya Halkevi” adlı eserde açılışla ilgili olarak şu kayıtlara yer verilmiştir: “ Halkevleri bütün memleket evladının aynı çatı altında aynı iradeye doğru yürüyerek, yekdiğerini sevmesi, tanıması ve bütün evladını kucaklayan aynı ülkü aynı heyecan ile memleket için çalıştıran, sarsılmaz ve ayrılmaz bütünlük doğuran bir kutlu yuvadır" (Ü.Y.K.H., 1933: 2).

Ayrıca eserde Kütahya Halkevi'nin bundan sonraki faaliyetleri hakkında da bilgi verilmektedir. "Bu memleketin, şimdiye kadar düşünülmemiş, akla gelmemiş birçok kültür hazineleri, halkevlerinin türlü araştırmalarıyla meydana çıkacaktır. $\mathrm{Bu}$ memleket halkı arasında asırlardan beri söylenen, millî melodiler, havalar halkevlerinin uyanık ve müteşebbis gençlerinin eliyle musiki tekniğinin ölçüsünden geçecek ve beynelmilel, ebedî, bestesi olacaktır. Halkevleri memleketimizin tarihi, eski eserleri, musiki üzerinde kıymetli tetkikler yaparak tükenmez hazinelerde memleketimizi zenginleştirecektir (Ü.Y.K.H., 1933: 4).

\section{O 1.1.Teşkilat Yapısı}

24 Haziran 1932 de açılan Kütahya Halkevi'nin müze ve sergi şubesi dışında, tüm şubelerde faaliyete başladı. Üye sayısına bakılacak olursa faaliyet raporlarında halkevine kayıtlı üyelerin sayısındaki artış ya da azalma halkevi başarısını gösteren bir ölçüt olduğundan, bir aylık bir zamanda ulaşılan üye sayısı Kütahya Halkevi'nin başarısı açısından önemlidir.

Tablo 1.1: Kütahya Halkevi Şubeleri ve Üye Sayıları

\begin{tabular}{|l|l|l|}
\hline Şube Ad1 & Açılış Tarihi & $\begin{array}{l}\text { Üye } \\
\text { Sayısı }\end{array}$ \\
\hline 1.Dil, Tarih,Edebiyat & 19 Temmuz 1932 & 50 \\
\hline 2.Güzel Sanatlar & 19 Temmuz 1932 & 49 \\
\hline
\end{tabular}




\begin{tabular}{|l|l|l|}
\hline 3. Spor & 14 Temmuz 1932 & 65 \\
\hline 4.Temsil & 2 Temmuz1933 & 33 \\
\hline 5.Sosyal Yardım & 19 Temmuz 1932 & 129 \\
\hline $\begin{array}{l}\text { 6.Halk Dershaneleri ve } \\
\text { Kurslar }\end{array}$ & 19 Temmuz 1932 & 109 \\
\hline 7. Kütüphane Ve Yayın & 19 Temmuz 1932 & 60 \\
\hline 8. Köycülük & 19 Temmuz 1932 & 224 \\
\hline Toplam & & 719 \\
\hline
\end{tabular}

Kaynak: B.C.A.1933 Y1lı F.R.,1933:2.

1935 yılına gelindiğinde üye sayısı aşağıda tablodaki gibidir.

Tablo 1.2: 1935 Yılında Şubelere Kayıtlı Üye Sayısı

\begin{tabular}{|l|l|}
\hline Şube & Üye Sayıs1 \\
\hline Dil, Tarih ve Edebiyat & 28 \\
\hline Güzel Sanatlar & 68 \\
\hline Temsil & 51 \\
\hline Spor & 90 \\
\hline Sosyal Yardım & 134 \\
\hline Halk Dershanesi ve Kurslar & 25 \\
\hline Kütüphane ve Yayın & 12 \\
\hline Köycülük & 224 \\
\hline Toplam & 632 \\
\hline
\end{tabular}

Kaynak: B.C.A.1935, K.H 1935 Yılı Ç.R.Ö

Tablo 1.3:1937 Yı1ı Şubelere Kayıtlı Üye Sayısı

\begin{tabular}{|l|l|}
\hline ŞUBE ADI & ÜYE SAYISI \\
\hline Dil, Tarih ve Edebiyat & 29 \\
\hline Güzel Sanatlar & 72 \\
\hline Temsil & 83 \\
\hline Spor & 107 \\
\hline Sosyal Yardım & 129 \\
\hline Halk Dershaneleri ve Kurslar & 69 \\
\hline Kütüphane ve Yayın & 152 \\
\hline Köycülük & 252 \\
\hline Toplam & 893 \\
\hline
\end{tabular}

Kaynak: B.C.A:1937, K.H 1937 Y1lı Ç.R.Ö

1937 yılına gelindiğinde üye sayısı tabloda da görüldüğü artış göstermiştir. Özellikle kütüphane ve yayın şubesinin üye sayısındaki artış dikkat çekicidir. Bunu konferans ve okuma-yazma faaliyetlerine verilen ağırlıkla açıklamak mümkündür. Ayrıca her halkevinin bulunduğu yerde bir kütüphane ve bir okuma odası açmak zorunludur. Talimatnamede en az 3 şubesi olan bir halkevinin, bir şubesinin muhakkak kütüphane ve yayın şubesi olması 
gerektiği belirtilmiştir. Şubenin genel anlamda bu öneminin yanında kütahya halkevinin kurucu başkanı olan halil kadri beyin şehirdeki gazete ve matbaa sahibi olması bu şubenin faaliyetlerini olumlu yönde etkilemiştir. Kütahya halkevine ait bir süreli yayının olmamasına rağmen günlük pratik bilgileri içeren el kitabı, bir kısmı ciddi bilimsel özellik taşıyan eserler, broşürler halkevlerinin kütüphane ve yayın şubesi üyelerinin çalışmaları sonucudur.

\subsection{Halkevi Başkanları}

Halkevi tüzüğüyle belirlendiği üzere halkevi başkanları idarî heyet tarafından seçilmekteydi. Kütahya Halkevi başkanlarına bakıldığında bunların şehrin ileri gelen eğitimli kişiler olduğu görülmektedir. Özellikle Halil Kadri ismi öne çıkmaktadır. Halil Kadri Kütahya'nın kurucu halkevi başkanı olmasının yanında, vilayet matbaasının da sahibidir. Halkevi başkanlarının faaliyetlerine bakıldığında, mesleğine uygun şubelerde faaliyet gösterdikleri görülür. Verimi arttırmaya yönelik bu uygulamanın bir sonucu olarak; Halil Kadri'nin matbaa sahibi oluşu Kütahya halkevi yayıncılığında önemli faaliyetlerde bulunmasına neden olmuştur. Halil Kadri başkanlık yapmadığı dönemlerde de halkevinde aktif rol oynamıştır.

Bunun yanında dikkat çeken bir diğer nokta, örneği fazla görülmeyen kadın halkevi başkanıdır. Sadece emekli bir öğretmen olduğunu öğrendiğimiz Fatma Dural bu konuda Kütahya Halkevi'nin öne çıkmasına neden olmuştur. Aşağıdaki Kütahya Halkevi başkanlarını gösteren tablo, yazışmaların altındaki imza sahiplerinin tespit edilmesiyle oluşturulmuştur.

Tablo 1.4: Kütahya Halkevi Başkanları

\begin{tabular}{|l|l|}
\hline Y1llar & Halkevi Başkanları \\
\hline $1932-1935$ & Halil Kadri \\
\hline 1936 & Nuri Erman \\
\hline $1937-1939$ & Fatma Dural \\
\hline 1940 & Selahattin Cemal Kutman \\
\hline 1941 & Emin Toktar \\
\hline 1942 & Emin Atac1 \\
\hline $1943-1944$ & Zihni Kutlu \\
\hline 1945 & Hamdi Halit Yener \\
\hline 1946 & Talat Çini, Remzi Ergene \\
\hline 1947 & Remzi Ergene \\
\hline
\end{tabular}

Kütahya halkevi başkanlarından Selahattin Cemal Kutman, Kütahya halkevi'nin kuruluşundan itibaren aktif rol üstlenmiştir. 1904 Geyve doğumludur. Darülfünun Eczacı Mekteb-i Alisi mezunudur. 1929 yılında partiye girmiş ve halkevi başkanlığı yaptığı 1939 yılına kadar partinin il teşkilatlanmasında çeşitli görevlerde çalışmıştır. Parti namına bulunduğu görevlerin çoğunluğunu sportif faaliyetler oluşturmaktadır. Fransızca bilen Kutman, eczacılık mesleğini serbest olarak yapmıştır. Halkevi reisliğine seçildiğinde belediye 
azalığından, ticaret odası başkanlığından ve spor bölgesi asbaşkanlığından istifa ederek bu göreve başlamıştır (B.C.A., S.S. 30/11/1939).

Kütahya Halkevi kurucu üyelerinden Hamdi Yener 1905 yılında İstanbul'da doğmuştur. Berlin Fernschule Teknik Enstitüsü'nden 1940 yılında mezun olan Yener'in mesleği müteahhitliktir. 1936 yılından itibaren aralıksız olarak halkevinde çeşitli komite başkanlıklarında görev almış Almanca bildiği için halkevi lisan kurslarında da hocalık yapmıştır (B.C.A, S.S. 15 /07/1944). Kütahya halkevinin diğer başkanları hakkında bir bilgiye ulaşılamamıştır.

\section{o 2. Kütahya Halkevi'nin Şubeleri ve Faaliyetleri}

Kütahya Halkevi şubelerinin tamamının 1932 tarihinde açıldığı görülür. Müze ve sergi şubesi dışında tüm şubelerle faaliyet gösteren Kütahya Halkevi faaliyetleri, yönetmeliğe uygun şekilde belirlenmiş, şube başkanları da mesleğine uygun şubelerde faaliyet göstererek, verim arttırılmaya çalışılmıştır.

\subsection{Dil, Tarih ve Edebiyat Şubesi ve Faaliyetleri}

19 Temmuz 1932'de açılan bu şubenin üye sayısı 50'dir. 1933 yılı faaliyet raporuna göre halkevinde gerçekleştirilen muntazam toplantılarda ilmî ve tarihî hasbıhallerin yapıldı̆̆ı görülmektedir. Dil, tarih, edebiyat kolunun genel amaçları düşünüldüğünde, Kütahya Halkevi'nde yapılan faaliyetlerin bu amaçların paralelinde yürütüldüğü söylenebilir.

1933 yılı faaliyet raporuna göre Kütahya Halkevinin aynı yıl içerisinde şu faaliyetleri yaptığı görülmektedir:

1-Dede Korkut masallarını izahlı okuma programı yapılmıştır.

2-Kütahya'da çalınan ve söylenen kıymetli türkülerin tamamı toplanmış ve Kütahya Gazetesi'nde neşredilmiştir.

3-Köylerde gezinti yapılmış ve türkülerin ağıt edilmesi sağlanmıştır.

4-Kütahya'da söylenen ve yaşayan sözlerin, kelimelerin tamamen toplanarak Ankara Dil Cemiyeti'ne gönderilmesi (bu kelimelerin adedi 2500ü bulmuştur) sağlanmıştır.

5-Anadolu'nun eski hizmetine dair bazı ecnebi eserlerden tercümeler yapılmış ve Kütahya Gazetesi'nde neşredilmiştir.

6-Frikya ve Eti medeniyeti üzerine yazılar yazılmıştır.

7-Dilimize dair tarihimizin eskiliği, Cumhuriyet devrindeki tarih telakkisine dair müteaddit konferanslar verilmiştir (Ü.Y.K.H., 1933:5).

1935 tarihli faaliyet raporunda ise yapılan faaliyetler şöyle sıralanmaktadır:

1-Dil devrimi için harç ve araç toplamak, ileride hazırlanacak Büyük Türk Sözlüğü için kaynak almak maksadıyla 500 kadar kelime toplanmıştır. 
2-Dilimizin gramer yapısının yükseltmek ülküsüyle açılan sentaks (nahru) anketleri üstünde yapılan çalışmalar dahilinde 30 masal toplanmış, 20 kadarı fişlere geçirilmiştir.

3-Kılavuz komisyonunun verdiği "Her Gün Beş Kelime” listesi çoğaltılarak gazete almayanlara ve üyelere dağıtılmıştır.

4-Osmanlıcadan Türkçeye türlü karşılıkların kullanış yerlerini belirterek, yaymak dileğiyle bir dil kursu açılmıştır.

5-Devrimin türlü yönlerini olduğu gibi dil, tarih ve edebiyatımızın geçirdiği büyük değişiklikleri aydınlatan konferans, söylev ve aytalar verilmiştir. (yayın ve sosyal yardım koluyla birlikte verilen bu sözlü yayınların sayısı 60’ı bulmaktadır)

6-2 Eylül Dil Bayramı, gündüz ve gece büyük ilgililer topluluğu ile kutlanmıştır. Gündüz lise öğretmeni Eflatun Güney, gecede lise direktörü Kazım Gürpınar, Atatürk'ün Türk Devrimi’ni türlü yönleriyle anlatmışlardır. Bu günün programına yalın dille, yamalı dil arasındaki ayırımı aksiyon halinde gösteren "Zor Nikâh " gösteriye konulmuştur.

7-Çavdarhisar örenleri gezilmiş ve Kütahya tarihi için incelemeler yapılmıştır. Antik izlere dair araştırmalar yapılmış, Kütahya tarihine ait maddeler, belgeler toplanmıştır (B.C.A:1935, K.H 1935 Y1lı Ç.R.Ö, No1208,1).

Tablo 2.1: 1935 Y1lı Dil, Tarih ve Edebiyat Şubesi Faaliyetleri

\begin{tabular}{|c|c|c|c|c|}
\hline \multirow{3}{*}{ 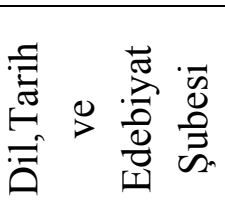 } & \multicolumn{2}{|c|}{ Komite } & \multicolumn{2}{|c|}{ Şube } \\
\hline & $\begin{array}{c}\text { Toplantı } \\
\text { Sayısı }\end{array}$ & Katılan Kişi & $\begin{array}{c}\text { Toplantı } \\
\text { Sayısı }\end{array}$ & Katılan Kişi \\
\hline & 8 & 27 & 3 & 45 \\
\hline
\end{tabular}

Kaynak: B.C.A:1935, K 1935 Ç.R., No1208:1

1938 yılında yayınlanan 1937 y1lı ikinci altı aylık rapora göre dil, edebiyat ve tarih kolu çalışmaları şu şekildedir:

1- Millî bayramlarda ve büyük günlerde yapılan toplantıları canlı ve hareketli bir suret kazandırmaya, millî heyecanlar sıcak tutulmaya çalışılmıştır.

2- Halkın kültür seviyesini yükseltmek, halkı inkılâp fikirleriyle şuurlandırmak, Kemalist prensiplerle ruhlandırmak için 36 konferans ve hitabet tertip edilmiştir.

3- Türk ruhunu, Türk zevkini sonsuzlaştıran halk şiirleri toplanmış ve mahallî gazetede neşredilmiştir.

4- Halk dilinde yaşayan söz cevherlerini derleme işi devam ettirilmiştir.

5- Kütahya mesireleri, mesire eğlenceleri ve mahalli oyunlar tespit edilmiş ve gazetede uzun bir tefrika halinde neşredilmiştir.

6- Tarihi izler korunmaya, tarihî vesikalar toplanmaya devam edilmiştir. Bu amaçla komite üyelerinden Mustafa Yeşil tarafından "Kütahya Tarihi” adında bir eser neşredilmiştir (B.C.A:1937, K.H 1937 Yı1ı Ç.R.Ö, No:989.829.1,4). 
Tablo 2.2: 1935 Y1lında Dil,Tarih ve Edebiyat Şubesi Tarafından Verilen Konferanslar

\begin{tabular}{|c|c|c|c|}
\hline Konu & Yazar & Tarih & Açıklama \\
\hline Cumhuriyet ve İnkılâp & Hayri Aksoy & $30 / 10 / 1935$ & Cumhuriyet Bayram1 \\
\hline İnk1lâbın Önemi & Talip & $30 / 10 / 1935$ & Cumhuriyet Bayramı \\
\hline Cumhuriyet Ne Yaptı? & Osman Ünver & $30 / 10 / 1935$ & Cumhuriyet Bayram 1 \\
\hline Cumhuriyet Ne Yaptı? & Hasan & $30 / 10 / 1935$ & Cumhuriyet Bayramı \\
\hline $\begin{array}{ll}\text { Eski Durumla } & \text { Yeni } \\
\text { Devrimize Toplu Bakış } & \end{array}$ & Safa & $30 / 10 / 1935$ & Cumhuriyet Bayram \\
\hline $\begin{array}{lll}\text { Cumhuriyete } & \text { Karşı } & \text { Özlü } \\
\text { Duygular } & & \end{array}$ & Ali Riza & $30 / 10 / 1935$ & Cumhuriyet Bayramı \\
\hline Cumhuriyet Ne Yaptı? & Alaattin & $30 / 10 / 1935$ & Cumhuriyet Bayramı \\
\hline Devrimizin Özlülüğü & Mehmet & $30 / 10 / 1935$ & Cumhuriyet Bayramı \\
\hline $\begin{array}{l}\text { Hastane Temel Atma } \\
\text { Merasimi Münasebetiyle }\end{array}$ & Dr. N. Seçkin & $30 / 10 / 1935$ & Cumhuriyet Bayramı \\
\hline Tifo ve Korunma Yolları & Dr. Sait Keskin & $23 / 11 / 1935$ & Halkevinde \\
\hline Artırım Yedi Günün Anlamı & Kazım Gürpınar & $14 / 12 / 1935$ & Müsamerede \\
\hline Yerli Malı & Arif & $14 / 12 / 1935$ & Sinemada \\
\hline Endüstrileşme & Alaattin & $14 / 12 / 1935$ & Sinemada \\
\hline Ulusal Artırım & Safa & $14 / 12 / 1935$ & Sinemada \\
\hline Yerli Malı & Talat & $14 / 12 / 1935$ & Sinemada \\
\hline Özgür Ekonomi & Orhan & $14 / 12 / 1935$ & Sinemada \\
\hline Millet İktisadiyatı & Kazım & $14 / 12 / 1935$ & Sinemada \\
\hline Yerli Mallarımız & Ali Riza & $14 / 12 / 1935$ & Sinemada \\
\hline Ekonomisel Ödevimiz & Hamdi Mengüç & $18 / 12 / 1935$ & Halkevinde \\
\hline $\begin{array}{l}\text { Hava Tehlikesi Karşısında } \\
\text { Korunma Şekilleri }\end{array}$ & Yzb. Ferit & $18 / 12 / 1935$ & Halkevinde \\
\hline
\end{tabular}

Kaynak: B.C.A:1937, K.H 1937 Y11ı Ç.R.Ö, No:989.829.1,4.

Tabloda görüldüğü gibi, 1935 y1lı içinde verilen toplam 20 konferanstan 8'i Cumhuriyet ve Türk İnkılâbı hakkındadır. Bunda, millî şuuru kuvvetlendirme, halk kitleleri arasında inkılâpların özümsenmesini, gerek gençlerin, gerekse yetişkinlerin Cumhuriyetin ülküleri doğrultusunda yetişmesini sağlama düşüncesi etkili olmuştur.sağlık alanındaki konferanslar daha çok koruyucu hekimlik konularında yoğunlaşmaktadır.bir diğer nokta özellikle milli bayramların, dil tarih ve edebiyat şubesinin amaçlarını gerçekleştirmek adına aktif olarak değerlendirildiği görülmektedir.

\subsection{Güzel Sanatlar Şubesi ve Faaliyetleri}

$\mathrm{Bu}$ şube teşekkül ettiği tarihten başlayarak düzenli olarak çalışmalar yapmıştır. Haftanın belli günlerinde halkevindeki musiki salonunda egzersizlerine devam etmekle beraber, birçok gecelerde konserler vermiştir. 
$\mathrm{Bu}$ şubenin hedefi alafranga musiki zevkinin memlekette yerleşmesini sağlamaktır. Bunun yanında şehir ve köylerde halk arasında yaşayan mahallî 6 zeybek havası ve birçok türkülerin besteleri tespit edilmiştir. Cumhuriyetin 10. Yıl Marşı'nın en küçük çocuklara varıncaya kadar bütün memleket halkına öğretilmesinde büyük emek vermiştir (Ü.Y.K.H.,1933:5).

1935 tarihli “103 Halkevi Geçen Yıllarda Nasıl Çalıştı?” isimli eserde Kütahya ile ilgili kısımda güzel sanatlar şubesinin o dönemki faaliyetinin kısa bir özeti vardır. Burada bu komitenin 3 halk sazı gecesi düzenlediği, küçük bir salon orkestrası kurduğu, 12 kişiye musiki kursu açtı ̆̆ , iki konser verdiği, kurulan orkestranın bütün törenlere katıldığı, yerel havalardan 20 tanesini notaya aldığı bilgilerine yer verilmiştir (C.H.P. G.S., 103 H.G.Y.N.Ç, 19321935:74-75).

1935 Senesi faaliyet raporlarında şubenin çalışmalarıyla ilgili olarak şu bilgilere yer verilmiştir:

1- Halk Saz Faaliyetleri: Ulusal müziğge araç ve harç verecek olan halk musikisini canlı ve Türk'ün iç uyumunu gösteren türkü, koşum ve deyişlerimizi unutturmamak için türlü vesilelerle saz ve söz geceleri düzenlenmiş, dil bayramı, parti kurultayı, kurtuluş günlerinin kutlanmasına ayrı bir önem verilmiştir.

2- Modern Müzik Faaliyetleri: Halkevinde verilen gösteritlerin müzik faaliyetlerini yönetmek ve ayrıca modern müziğin tadını halka sunmak için küçük bir salon orkestrası oluşturulmuştur. Bir piyano, iki keman, bir mandolin ve bir flütten ibaret olan bu orkestra, 20 gösterit müziğiyle eşlik etmiş "Çınar, Himmetinoğlu” gibi müzikli piyeslerin beste kısmını yönetmiştir. Bundan başka orkestra büyük artistik eserlerde iki ayrı konser vermiştir.

3- Orkestra İçin Yeni Elemanlar: Kapasite bakımından elverişli bulunulan gençler teşvik edilerek, açılan müzik kursunda yetiştirilmeye çalışılmıştır (K.H.1935 Yılı F.R:1935:.43-44).

Tablo 2.3: 1935 Y1lı Güzel Sanatlar Şubesi Faaliyetleri

\begin{tabular}{|c|c|c|c|c|}
\hline \multirow{3}{*}{ 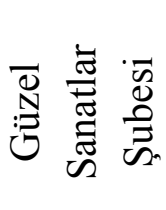 } & \multicolumn{2}{|c|}{ Komite } & \multicolumn{2}{|c|}{ Şube } \\
\hline & $\begin{array}{c}\text { Toplantı } \\
\text { Sayısı }\end{array}$ & Katılan & $\begin{array}{c}\text { Toplantı } \\
\text { Sayısı }\end{array}$ & Katılan \\
\hline & 4 & 10 & 8 & 70 \\
\hline
\end{tabular}

Kaynak: K. H.1935 y1lı F.R:1935,43-44.

Tablo 2.4: 1935 Y1lı Güzel Sanatlar Şubesi Sosyal Faaliyetleri

\begin{tabular}{|l|l|l|}
\hline Faaliyet & Sayı & Katılan \\
\hline Kongre & 2 & 130 \\
\hline Balo & 2 & 600 \\
\hline Şölen & 4 & 410 \\
\hline Nişan ve Nikah Töreni & 4 & 701 \\
\hline Çaylı Danslar & 5 & 590 \\
\hline Gösterit & 3 & 1700 \\
\hline
\end{tabular}




\begin{tabular}{|l|l|l|}
\hline Konser & 2 & 1000 \\
\hline Sinema & - & - \\
\hline Konferans & 8 & 1700 \\
\hline Birlikte Yapilan Toplantilar & 20 & 13400 \\
\hline
\end{tabular}

Kaynak: B.C.A., 103 H.G.Y.N.Ç, 1932-1935: 74-206-217.

Tablodan anlaşıldığı gibi, Güzel Sanatlar şubesinin 1935 yılındaki faaliyetleri kapsamında gösterit, konser ve konferans türü etkinliklere olan rağbet, diğerlerine göre daha yüksektir. Bu da, söz konusu etkinliklerin halk tarafından daha ilgi çekici bulunmasından kaynaklanmış olmalıdır. Ayrıca daha çok açık havada gerçekleştiğini tahmin ettiğimiz bu etkinlikler katılımı da büyük oranda etkilemiştir.

Şubenin 1937 senesi faaliyetleri şu şekilde belirtilmektedir:

1- Şubeye ait bandonun repertuarı zenginleştirmeye çalışılmaktadır.

2- Yeniden tesis edilen salon orkestrası Cumartesi ve Pazar günleri öğleden sonra ulusal günler ve eğlence geceleri için muayyen bir programla konserler hazırlamıştır.

3- Salon orkestrasına bir de flüt eklenmiştir.

4- Lise talebelerinden oluşan bir gruba iki ve üç sesli şarkılar öğretilmiş bu suretle saz ve ses konserlerinin ilerlemesi sağlanmıştır (B.C.A:1937, K.H 1937 Yılı Ç.R.Ö., No: 989.829.1:4).

Tablo 2.5: 1937 Y1lı Güzel Sanatlar Şubesi Faaliyetleri

\begin{tabular}{|l|l|l|}
\hline Faaliyet & Faaliyet Say1s1 & Kat1lan \\
\hline Konser & 1 & 400 \\
\hline Resim Sergisi & 1 & 100 \\
\hline
\end{tabular}

Kaynak: B.C.A:1937, K.H. 1937 Yı11 Ç.R.Ö., No: 989.829.1:4.

\subsection{Spor Şubesi ve Faaliyetleri}

Spor şubesininin faaliyetleri daha çok güreş, futbol, avcılık gibi branşlarda yoğunlaşmıştır. Şubenin 1933 yılındaki faaliyetleri şöyledir:

1- Güreş: Halkevi içinde güreşler için salon ayrılmış, muntazam surette güreşler yapılmıştır. Eski bir spor olduğu için büyük rağbet görmüştür.

2- Futbol: Kütahya sporlarının vilayet muhtelif taraflarına giderek maç yapmaları sağlanmış, buna binaen Tavşanlı' da bir müsabakaya katılmıştır. Tavşanlı Halkevi Spor Şubesi sporcuları'da Kütahya'ya gelmiştir. Aynı şekilde Eskişehir'de bir müsabaka gerçekleşmiştir. Kütahya'lı sporcularının forma, ayakkabı, top, bayrak gibi lüzumlu teçhizatları halkevi tarafından karşılanmıştır. Kütahya'ya stadyum yapılması için halkevi bütçesine 1300 lira tahsilat konmuştur. Cumhuriyet Bayramı'nda Ankara'daki maç ve geçiş resmine katılmak üzere yirmişer kişilik iki sporcu kafilesi gönderilmiştir, 
3- Avcılık: Kütahya Halkevi, spor işleri arasında avcıllğa çok ehemmiyet vermiş av gezintileri ve avcılar bayramları tertip etmiştir. 1932 Eylül'ündeki bayrama 90 avcı, 1933 yılındaki bayrama ise 120 avcı iştirak etmiştir. Bu bayramlar Porsuk Çayı kaynağında tertip edilmiştir (Ü.Y.K.H.,1933:6).

Spor şubesinin 1935 yılındaki faaliyetleri şu şekilde gerçekleşmiştir:

1- Spor şubelerinden futbol ve güreş üzerinde çalışan kulüp ve elemanlarının tekâmülü için elden gelen yardım ve teşvik yapılmış, bu örgütlerin güçlenmesi için her türlü aracın hazırlanmasına çalışılmıştır.

2- Köycüler koluna bağlı bir atlı kol oluşturularak üç gezi tertip edilmiştir. Güreş için halkevi salonu tahsis edilmiştir. Ayrıca 1935 yılı faaliyet raporuna göre Kütahya Mevlevihanesi'nin kapalı güreş yeri olarak kullanıldı̆̆ı bilgisi de yer almaktadır. (B.C.A: K.H., 1937 Yılı Ç.R.Ö. 1937:38).

3- Sporun hakkıyla canlanıp, gelişmesinde ihtiyaç duyulan stadın yapılması için bir yandan resmi girişimlerde bulunulmuş, bir yandan da halkevi bütçesinden kaynak ayrılmıştır (B.C.A., K.H 1937 Yılı Ç.R.Ö. 1937:38).

4- Millî güreş kaptanı Salim Bey, iki kez şehre gelişinde halkevi güreşçileriyle meşgul olmuş, egzersiz yaptırmıştır. Halkevi güreşirleri eski şampiyonlardan Teğmen Münir'in nezareti altında da çalışmıştır,

5- Spor komitesi başkanı ve üyelerden toplam 3 kişinin ilden ayrılması dolayısıyla tekrar seçim yapılmış, bu komite yeni baştan faaliyet yollarını çizmiştir (B.C.A., K.H 1937 Y1lı Ç.R.Ö., 1937:47).

Tablo 2.6: 1935 Y1lı Spor Şubesi Faaliyetleri

\begin{tabular}{|c|c|c|c|c|}
\hline \multirow{3}{*}{ 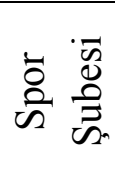 } & \multicolumn{2}{|c|}{ Komite } & \multicolumn{2}{|c|}{ Şube } \\
\hline & Toplantı Sayı1s1 & Katılan & Toplant1 Sayı1s1 & Katılan \\
\hline & 5 & 22 & 11 & 400 \\
\hline
\end{tabular}

Kaynak: B.C.A., K.H. 1935 Yılı Ç.R.Ö.,1935: 47.

Kütahya Halkevi'nin 1937 senesi ikinci altı aylık çalışmasını anlatan raporda, şubenin altı aylık çalışması şube başkanı tarafindan özetlenmiştir. Şube başkanı Selahattin Kutman'ın özetlediği altı aylık çalışma raporundan şu sonuçlar çıkmaktadır:

“ Haziran 1937 ayında verilmiş olunan altı aylık çalışma raporunda kulüplerin birleştiği ve yakında stadyum inşasına başlanacağı belirtilmiş, bu sayede spor faaliyetlerinin daha intizama gireceği kanaatinde bulunmuştur" (B.C.A:1937, K.H 1937 Y1lı Ç.R.Ö., 47).

Tablo 2.7: 1937 Y1lı Spor Şubesi Faaliyetleri

\begin{tabular}{|c|c|c|c|c|}
\hline \multirow{3}{*}{ 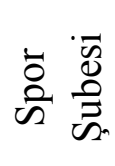 } & \multicolumn{2}{|c|}{ Komite } & \multicolumn{2}{|c|}{ Şube } \\
\hline & Toplantı Sayıs1 & Katılan & Toplantı Sayıs1 & Katılan \\
\hline & 4 & 10 & 1 & 63 \\
\hline
\end{tabular}


Kaynak: B.C.A., K.H 1937 Y1lı Ç.R.Ö., 1937:47

\subsection{Temsil Şubesi ve Faaliyetleri}

Temsil şubesinin, faaliyetlerini gerçekleştirebilmesi için 300 kişi alan, Kütahya halkevi salonunda mükemmel bir sahne yaptırılmakla işe başlanmış, sahnede temsil komitesiyle, mektepler ve dışarıdan gelen mümtaz heyetler tarafindan temsiller ve müsamereler verilmiştir.

1932 yılı Cumhuriyet Bayramı'nda temsil komitesi "Mavi Yıldırım" ve "Şer'iye Mahkemesinde" piyeslerini başarıyla temsil etmiştir. Lisenin halkevi sahnesinde verdiği "İstiklal" ve "Yarım Osman" piyesleri de çok alaka ve heyecan uyandırmıştır. Temsil komitesinde bilhassa muallim hanım ve beylerin bu sahadaki muvaffakiyetli çalışmalarının olumlu sonuçları olmuştur. Komiteye fırkanın gönderdiği piyeslerden başka dram ve komedi nevinden de eserler temin edilmiştir (CHPG.S.,103 H.G.Y.N.Ç, 1932-1935:74-75).

Kuruluşunun ilk birkaç yılında güçlü bir varlık gösteremeyen, parlayıp sönen kol, milletvekili Nahit Uluğ'un verdiği destekle 1935 yılı ortalarında canlanmış ve az zaman içinde en önemli çalışma şubesi hâlini almıştır.1935 senesi faaliyet raporunda şubenin çalışmalarıyla ilgili şu bilgilere yer verilmiştir:

1-Sahnenin dekor ve 1şık tertibatı kola bağlı üyeler tarafından tertip edilmiş, kolda öğretmen ve işyarlardan başka serbest meslek sahiplerinin de görev aldığı ve sanat bakımından büyük başarılar gösterdikleri görülmüştür.

2-Sahnede 10 eser, 20 defa gösterilmiş, bu eserler arasında "Çınar, Himmetinoğlu ve Kör”, büyük ilgi uyandırmıştır.

3-Halkevinde gösterilerin sıklaştırılması, gösteri kolunun yani temsillerde hazırlık evresinde sahnenin boş bırakılmaması için liselilerden faydanılmıştır. Bu suretle gösteri kolu ve liseliler tarafından bu yıl içinde 10 eser 20 defa gösterilmiştir (B.C.A., K.H 1935 Yılı Ç.R.Ö.1935:3).

Tablo 2.8: 1935 Y1lı Temsil Şubesi Faaliyetleri

\begin{tabular}{|l|l|l|l|}
\hline Gösterilen Piyesler & $\begin{array}{l}\text { Gösterim } \\
\text { Tekrarı }\end{array}$ & Tarih & İzahat \\
\hline Kürsüden Uzakta & 3 & $23,24,25 /$ Nisan/1935 & Halkevi \\
\hline $\begin{array}{l}\text { Bir Mahkumun Son } \\
\text { Günü }\end{array}$ & 2 & $26 /$ Nisan/1935 & Liseliler \\
\hline Gömdüğüm O Cihan & 2 & $11 /$ Haziran/1935 & Halkevi \\
\hline Himmetinoğlu & 2 & $21,22 /$ Eylül/1935 & Halkevi \\
\hline
\end{tabular}




\begin{tabular}{|l|l|l|l|}
\hline $\begin{array}{l}\text { Himmetinoğlu(Kört } \\
\text { Köyü) }\end{array}$ & 1 & $13 / 10 / 1935$ & Halkevi \\
\hline Zor Nikah & 1 & $26 /$ Eylül/1935 & Halkevi \\
\hline Çınar & 2 & $28,30 /$ Ekim & Halkevi \\
\hline Kızıl Çağlayan & 2 & $01 /$ Şubat/1935 & Liseliler \\
\hline Kör & 2 & $19 /$ Ekim/1935 & Halkevi \\
\hline Kör & 1 & $11 /$ Ekim/1935 & Öğretmen \\
\hline Kürsüden Uzakta & 1 & $14 /$ Aralı/1935 & Liseliler \\
\hline
\end{tabular}

Kaynak: B.C.A., K.H. 1935 Yılı Ç.R.Ö.1935: 45.

Kütahya Halkevi 1935 yılı faaliyet raporunda ayrıca eserlerin halkta uyandırdığı etkiye de yer verilmiştir. Bunlardan bazıları şu şekildedir:

"Himmetinoğlu: Eser her türlü halk kiplerini artistik bir objektif altında çok canlı olarak ifade ettiği için seyirciler bu kahramanların şahsında aralarında yaşadıkları insan örneklerini bulmuş ve bunun verdiği heyecanla esere üstün bir ilgi gösterilmiştir. Ayrıca eser şehirdeki etkiyi köylüler üzerinde de bırakmış ve Altıntaş Nahiyesi'nde 20 köyden merkeze toplanan halk da, bu temsile karşı aynı alakayı göstermiş ve bunu duyan diğer nahiyeler, kolu köylerine çağırmışlardır” (B.C.A.,K.H. 1935 Yılı Ç.R.Ö.,1935:43).

"Çınar: Devrim konularını tablo ve 1şık halinde sunan bu eserin, seyircilerin görsel zevkini tatmin ettiği vurgulanmış, ancak halk zevkine ve düzeyine göre ayarlanmış olsaydı etkilerinin daha büyük olacağı ifade edilmiştir” (B.C.A., K.H. 1935 Y1lı Ç.R.Ö., 1935: 45).

"Kör: Sosyal problemlerden dedikoduyu anlatan eserin tez yönünden kuvvetli olduğu vurgulanmış, ilgi ve ahlaki etkilerinin görüldüğü ifade edilmiştir. Gösteritlerin dil, yayın, modern müzik zevkinin aşılmasını kolaylaştırması bakımından köylüleri de ilgi ile toplamak adına, köycülük koluna en güçlü desteği sağladığı ifade edilmektedir” (B.C.A., K.H. 1935 Yılı Ç.R.Ö., 1935: 45).

“Gösterit kolu başkanının ve üyelerinden bir kaçının 1937'nin altı ayı içinde şehirden ayrılması hasebiyle, ilk 3 ay içinde geniş bir faaliyet icrasına imkan görülmemiş, ancak işin teslim alındığı 20.10.1937 tarihinden itibaren planlı bir çalışmaya geçilmiştir. İlk önce "İstiklal" piyesi, onu takiben "Taş Parçası" piyesleri temsil edilmiş ve halk tarafından beklenen ilgiyi görmüştür. Halkevlerinin açılış günü olan 20 şubat gününde temsil edilmek üzere, "Tırtıllar" piyesi seçilmiş, rolleri dağıtılmış ve aynı hafta içinde ilk provası yapılmıştır" (K.H.1937 Y111 2.A.A.F. R.,1937: 2).

1937 gösterit kolu başkanı Nurullah Arıkök imzalı komitenin bu faaliyetlerini açıklayan raporda, temsillerde kadın unsurunun ön plana çıkarılması ile ilgili olarak şu ifadelere yer verilmektedir: "Temsil heyeti üyelerinden bilhassa kadın unsurunun gösterdikleri çekingenliğin, son zamanlarda ulusal ve kültürel davaya karşı bir sevgi ve isteğe dönüşmüş olduğu ve temsil vermekteki müşkülatı doğuran bu en mühim amilin ortadan kalkmış olduğu memnuniyetle görülmektedir" (K.H.1937 Y111 2.A.A.F.R., 1937: 2). 
21.05.1941 tarih ve 39 sayılı Kütahya Halkevi’nden CHP Genel Sekreterliği'ne gönderilen yazıda, köylerde sinema filmi göstermek için film istendiği öğrenilmektedir. Cevaben yazılan 14.06.1941 tarihli yazıdan, bu teşebbüsün desteklendiği ve film gönderebilecekleri sonucu çıkmaktadır. Ancak makine, makineyi kullanacak zat, bu işi idare edecek kimselerin, maksada tamamıla hizmet edebilecek kabiliyette ve gönderilen filmlere hasar vermeden iade edebilecek vaziyette bulunmaları şartı konmuştur (CHP H.B.A. 14.06.1941 8.361135 S.Y.).

Yazışmalar esas alındığında filmlerin bir hat üzerinden geçtiği anlaşılmaktadır. Afyon- Kütahya- İzmir- Balıkesir- Çanakkale- Bandırma- İzmit- Bursa- Mustafa Kemal Paşa hattını takip eden filmler, en çok beş gün süreyle gösterilmekte ve bir sonraki halkevine gönderilmektedir. Filmler gerek teslim alındığında, gerek teslim edildiğinde, genel sekreterliğe yazıyla bildirilmek zorundaydı (C.H.P. H.B.A:1942, 8-52610 S.Y.).

Yazışmalardan anlaşıldığı kadarıyla 09.12.1942'de "Kile Verilen Renkler" filmi; 06.02.1942'de "Donanmamızın Malta Seyahati”; 06.07.1946'da “CHP Olağanüstü Kurultayının Açılışı”, "Kadınlarla Röportaj”, "Erkeklerle Röportaj” adlı üç film; 19.08.1946'da "Sümerbank'ın Çalışması" adlı filmler teslim alınmıştır (CHP H.B.A:1942, 6/7/1942,6/7/1946,19/8/1946 T.Y.).

\subsection{Sosyal Yardım Kolu Şubesi ve Faaliyetleri}

Şube, Kütahya'nın yoksul çocuklarına yardım etmeyi ve mekteplerde okuyan kimsesizlere destek olmayı, köylerden gelen ve halkevine müracaat eden hastaların muayenesini, reçetelerinin yaptırılmasını kendine iş edinmiştir ( Ü.Y.K.H., 1933:7).

Şube'nin faaliyetleri 1933 yılı faaliyet raporlarında şöyle belirtilmektedir:

1- 2 sıhhi konferans verilmiş, 8 sıhhi makale yazılmıştır.

2- Yoksulların devamlı bir surette muayene ve tedavisi için halkevinde poliklinik açma çalışması tamamlanmıştır (Ü.Y.K.H.,1933:7-8).

1935 yılındaki kayıtlara göre şubenin yaptığı faaliyetler şöyle sıralanmıştır:

1-İl merkezi hekimlerinin iştirakiyle halkevi'ne halk için bir poliklinik açılmıştır. Burada her gün ve belli saatlerde müracaat eden hastalara bakılmıştır.

2-Köycüler ve gösterit kolu, birlikte Altıntaş Halkevi’ne giderek 160 köylü hastaya evlerinde bakmış, halka kinin dağıtmış, sağlık halkında öğ̈̈tler vermiştir.

3-Halka ve öğretmenlere mahsus olmak üzere CHP ve halkevi ile Öğretmenler Birliği binasında ve Derviş Paşa Okulunda zehirli gazlar hakkında konferanslar verilmiş, son defa halkevinde yapılan tifoya dair bir konuşma Kütahya Gazetesi'nde neşredilmiştir.

4-Yoksul halk ve bilhassa köylülere yardım olmak üzere, reçeteleri halkevi hesabına yaptırılmıştır (K.H. 1935 Y.F.R.,1935:3). 
1937 y1lı faaliyet raporuna göre komitenin başkanı Muhlis Göknar’dır. Bu tarihteki faaliyet raporuna bakıldığında şu sonuç çıkmaktadır: Geçen tarihlerde halkevinde açılan muayenehane ödenek sıkıntısı çekmektedir. Bu sıkıntılardan dolayı görevini tam anlamıyla yapamamıştır. Sosyal yardım koluna tahsis edilen otuz liranın muayenenin devamının sağlanmasının yanında hangi alanlarda kullanıldığı belirtilmiştir (K.H. 1937 Y.F.R.,1937:3).

Tablo 2.9: 1937 Y1lı Sosyal Yardım Kolu Faaliyetleri

\begin{tabular}{|c|c|c|c|c|}
\hline \multirow{3}{*}{ 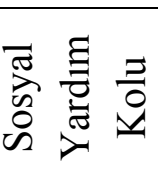 } & \multicolumn{2}{|c|}{ Komite } & \multicolumn{2}{|c|}{ Şube } \\
\hline & Toplantı Say1s1 & Katılan & Toplantı Sayıs1 & Katılan \\
\hline & 3 & 14 & 2 & 50 \\
\hline
\end{tabular}

\subsection{Halk Dershaneleri ve Kurslar Şubesi ve Faaliyetleri}

19 Temmuz 1932 tarihinde teşekkül etmiş olan bu şubenin 106 üyesi vardır. Kurulduğu yıl biri kadınlara, diğeri de erkeklere olmak üzere 2 halk dershanesi açılmış, bu dershanelerde 60 talebe okutulmuştur (Ü.Y.K.H., 1933: 7-8).

Halk Dershaneleri ve Kurslar Şubesi’nin 1933 yılındaki faaliyetleri şu şekilde gerçekleşmiştir:

1-1933 senesi yazında açılan makine ve otomobil kursuna 21 kişi devam etmiş ve sertifika almıştır.

2-1934 senesinde meslek kursları ile İngilizce ve Fransızca dersleri açılması planlanmıştır.

3-1934 senesinde açılacak İngilizce kursuna 18 Ocak’ta başlanması öngörülmüş, dersleri doktor Fazıl Bey’in vermesi ve haftada üç gün sürmesi planlanmıştır (K.H. 1933 Y.F.R.,1933:6).

17.12.1935 senesi itibariyle Kütahya merkezde bir kadın, bir erkek dershanesi bulunmaktadır. Bu dershanelerde 16'sı kadın olmak üzere toplam 45 öğrenci öğrenim görmüş, tatil günleri dışında her akşam derse devam edilmiştir.

1-Okulu olan köylerde halk dershaneleri açılması için sosyal yardım kolu vasıtasıyla kültür direktörlüğüne girişimlerde bulunulmuş ve bu işin bir an önce başarılması yolunda köy okullarına genelgeler gönderilmiştir.

2- Halkevinde bir dil kursu ile bir İngilizce kursu açılmış olup, örgenci sayısının çoğalması için teşviklerde bulunulmuştur. Bir Fransızca kursu açılması da planlanmıştır (K.H. 1935 Y.F.R.,1935:6).

1937 yılında, Kütahya Halkevi halk dershaneleri ve kurslar şubesi, okuma-yazma bilmeyen yurttaşlara hizmet için, üye olan öğretmenler arasında vazife taksimi yaparak 2 dershane açmıştır. Dershaneye hiç okuma-yazma bilmeyen 66 kişi kaydetmiştir. Yoklamalarda 58 kişinin muntazaman devam ettiği ve bu müddet zarfında kurstan verimli 
şekilde faydalandıkları görülmüştür. Müdavimlere parasız kalem, kitap temin edilmiş, dershane aydınlatması ve teçhizatı halkevi bütçesinden ayrılan 20 lira karşılanmıştır (K.H. 1937 Y. F.R.,1937:7).

Tablo 2.10: 1933 Y1l Halk Dersanesi ve Kurslar Şubesi Faaliyetleri

\begin{tabular}{|l|l|l|}
\hline Dershane Sayısı & Erkek Öğretmen Sayısı & Kadın Öğretmen Sayıs1 \\
\hline 3 & 55 & 20 \\
\hline
\end{tabular}

Kaynak: B.C.A.,K.H. 1933 Y. F. R., 1933: 12.

Tablo 2.11: 1937 Y1lı Halk Dersanesi ve Kurslar Şubesi Faaliyetleri

\begin{tabular}{|c|c|c|c|c|c|}
\hline \multirow{3}{*}{$\frac{y}{\bar{J}}$} & \multirow{3}{*}{ 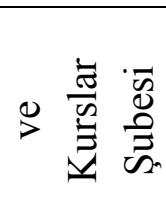 } & \multicolumn{2}{|c|}{ Komite } & \multicolumn{2}{|c|}{ Şube } \\
\hline & & $\begin{array}{c}\text { Toplantı } \\
\text { Sayısı }\end{array}$ & Katılan & Toplantı Sayıs1 & Katılan \\
\hline & & 6 & 25 & 8 & 150 \\
\hline
\end{tabular}

Kaynak: B.C.A., K.H. 1937 Y. F. R., 1937:7.

\subsection{Kütüphane ve Yayın Şubesi ve Faaliyetleri}

Bu şube 19 Temmuz 1932 tarihinde kurulmuştur. Üye sayısı 60’tır. İlk kurulduğunda 227 kitapla göreve başlayan şubenin, 1933 senesi içinde kitap sayısı 567'ye ulaşmıştır. Bunlardan bir kısmı halkevi bütçesinden, bir kısmı da tebernaslarla (bağış) elde edilmiştir. Açıldığı tarihten 1933'e kadar kütüphaneye devam eden okuyuculardan tespit edilenlerin sayıs1 2330'dur. Son üç ay içerisinde 446 kitap ciltlettirilmiştir.

Kütüphane ve Yayın Şubesinin 1935 yılındaki faaliyetleri şöyle sıralanmaktadır:

1- Kitapsarayı zenginleştirme faaliyetleri devam etmiştir.1935 yılı itibariyle 1550 kitap ile 1342 sayı dergi mevcuttur.

2- 1935 yılı içinde kitapsaraydan 3962 okuyucu faydalanmıştır.

3- Yayın faaliyetleri sözlü ve yazılı yayın olarak iki koldan devam etmiştir. Sözlü yayın faaliyetleri diğer kollarla işbirliği yapılarak, halk kürsülerinde gösteri ve sinema salonlarında söylevlerle, içeride konferans ve müsamere olarak değerlendirilmiş bayram, kurtuluş günü ve diğer önemli günler bu şekilde kutlanmıştır.

4- Yazılı yayın faaliyetleri de, her türlü sosyal olgu ve hadiselerle ilgili yazılar çıkarma, broşürler basma faaliyeti olarak devam etmiştir. Bu eserler hakkında Kütahya halkevi Neşriyatı kısmında ayrıntılı bilgi verilecektir. Burada sadece isimlerini belirtecek olursak bunlar; Devrim Andıcı, Kara Sinek, Kütahya Halk Şairleri gibi eserlerdir. Ayrıca halkevi tarafından Vilayet Gazetesi'ne yayınlanmak üzere yazılar gönderilmiştir. Bunlar şöyledir: 
Tablo 2.12: 1933-34 Yıllarında Çıkan Broşürler

\begin{tabular}{|l|l|l|}
\hline Adı & Yazar & Tarih \\
\hline Türkçe İçin Bir Konferans & İshak Refet & 1932 \\
\hline Kütahya'da Cumhuriyetin On Y1l & Halil Kadri Erden & 1933 \\
\hline Ülkü Yolunda Kütahya Halkevi & Halil Kadri Erden & 1933 \\
\hline Altı Ok & Halil Kadri Erden & 1934 \\
\hline Buhran Nedir? & Halil Kadri Erden & Tarihsiz \\
\hline İktisadi Devletçiliğimiz & Halil Kadri Erden & 1933 \\
\hline Kütahya Halk Şairleri & Mustafa Hakkı & Tarihsiz \\
\hline Devrim Andıcı & Halil Kadri Erden & Tarihsiz \\
\hline Kara Sinek ve Korunma Yolları & Dr.Nazif Seçkin & Tarihsiz \\
\hline
\end{tabular}

Kaynak: B.C.A.,K.H. 1935 Y.F.R. ,1935:7.

Tablo 2.13: 1935 Yılı Kütüphane ve Yayın Kolu Sözlü Yayınları

\begin{tabular}{|c|c|c|c|}
\hline Konu & Sözmenler & Tarih & Açıklama \\
\hline Kadınların İntihap Hakkı & Aliye Öğretmen & $03 / 02 / 1935$ & C.H.P \\
\hline Kadınların İntihap Hakkı & İsmet Öğretmen & $03 / 02 / 1935$ & C.H.P \\
\hline $\begin{array}{llll}\text { Halkevimiz } & \text { Bir } & \text { Yilda } & \text { Nel } \\
\text { Yaptı? } & & & \\
\end{array}$ & Eflatun Güney & $19 / 02 / 1935$ & C.H.P \\
\hline Büyük Partinin Büyük İşleri & Halil Kadri Erdem & $19 / 02 / 1935$ & C.H.P \\
\hline $\begin{array}{l}\text { Yazı İnk1lâbımızın Büyi } \\
\text { Verimleri }\end{array}$ & Kazım Gürpınar & $24 / 04 / 1935$ & Müsamere \\
\hline Dil İnk1lâbımız & Eflatun Güney & $26 / 04 / 1935$ & Müsamere \\
\hline $\begin{array}{lll}\text { Hava Tehlikesi } & \text { Karşısınn } \\
\text { Ulusal Görev } & \\
\end{array}$ & Eflatun Güney & $06 / 06 / 1935$ & Müsamere \\
\hline Hava Tehlikesi & Sadık Bey & 06/06/1935 & Müsamere \\
\hline $\begin{array}{l}\text { Gaz Tehlikesi ve } \text { Korunn } \\
\text { Yolları }\end{array}$ & Dr. Sait Keskin & $06 / 06 / 1935$ & Müsamere \\
\hline Car ve Peçe & Eflatun Güney & $23 / 04 / 1935$ & Müsamere \\
\hline Soy ve Şan Atılımı & Eflatun Güney & $11 / 06 / 1935$ & Müsamere \\
\hline Büyük Zafer & Abdullah Öğretmen & $30 / 08 / 1935$ & Müsamere \\
\hline Nüfus Sayımının Önemi & Selim Sabit & $12 / 09 / 1935$ & Müsamere \\
\hline Dilimizin Geçirdiği Evreler & Eflatun Güney & $26 / 09 / 1935$ & Dil Bayramı \\
\hline İnk1lâbın Şümul ve Önemi & Kazım Gürpınar & 26/09/1935 & Dil Bayramı \\
\hline Dil İnk1lâbının Önemi & Kazım Gürpınar & $28 / 10 / 1935$ & Müsamere \\
\hline $\begin{array}{ll}\text { Türkiye } & \text { Cumhuriyetin } \\
\text { Büyüklüğü } & \end{array}$ & Eflatun Güney & $29 / 10 / 1935$ & $\begin{array}{l}\text { Cumhuriyet } \\
\text { Bayramı }\end{array}$ \\
\hline
\end{tabular}




\begin{tabular}{|l|l|l|l|}
\hline Cumhuriyet ve İnk1lâp & Halil Kadri Erdem & $29 / 10 / 1935$ & $\begin{array}{l}\text { Cumhuriyet } \\
\text { Bayramı }\end{array}$ \\
\hline Cumhuriyet ve İnk1lâp & Aliye Özdoğan & $29 / 10 / 1935$ & $\begin{array}{l}\text { Cumhuriyet } \\
\text { Bayramı }\end{array}$ \\
\hline Cumhuriyet ve İnk1lâp & İbrahim Ertem & $29 / 10 / 1935$ & $\begin{array}{l}\text { Cumhuriyet } \\
\text { Bayramı }\end{array}$ \\
\hline Cumhuriyet ve İnk1lâp & Musa Kazım & $29 / 10 / 1935$ & $\begin{array}{l}\text { Cumhuriyet } \\
\text { Bayramı }\end{array}$ \\
\hline
\end{tabular}

Kaynak: B.C.A.,K.H. 1937 Y. F. R.,1937: 9.

1935 yılında kütüphane ve yayın şubesinin sözlü yayınları arasında Cumhuriyet ve İnkılâp konulu olanlarının ağırlıklı olduğu görülmektedir. Bunda, daha öncede ifade edildiği gibi, yapılan inkılâpların ve Cumhuriyetin kazanımlarının halk kitleleri tarafından özümsenmesi ve millî şuurun canlı tutulması fikrinin etkili olduğu anlaşılmaktadır.

Kütüphane ve Yayın şubesinin 1937 yılındaki faaliyetleri şöyle sıralamak mümkündür:

1-Kütüphanedeki toplam kitap sayısı 1839'dan 1959'a ulaşmıştır.

2-Kütüphanenin altı aylık okuyucu sayısı 1352'dir.

3-Dil bayramı, Cumhuriyet yıldönümü, Kızılay'ın 60. yıldönümü gibi günler vesilesiyle verilen konferans ve söylevler tespit edilerek bir kısmı aynen, bir kısmı da kısaltılarak Kütahya Gazetesi'nde neşredilmiştir.

4-Kütahya İli’ne gelen Kazım Nami Durul'un verdiği üç konferans gazetede neşredilmiştir.

5-Kütahya Gazetesi’nde "Bayrağa Sayg1, Kızılaya Yardım, İnkılâp, Gençlik" mevzuları üzerine yazılar yazılmıştır.

6-Kütahya'nın mesire gezmeleri, oyunları ve türküleri üzerinde yapılan etütlerin gazetede tefrika şeklinde neşrine başlanmıştır.

Tablo 2.14:1936 Y1lı Kütüphane ve Yayın Kolu Faaliyetleri

\begin{tabular}{|c|c|c|c|c|}
\hline త్ & & & & \\
\hline$: \widetilde{\nabla}$ & Toplantı Sayıs1 & Katılan & Toplantı Sayıs1 & Katılan \\
\hline$\forall>\Delta$ & 3 & 15 & 1 & 20 \\
\hline
\end{tabular}

Kaynak: B.C.A.,K.H. 1936 Y.F.R.,1936:18.

Tablo 2.15: 30/06/1937-01/01/1938 Tarihleri Arasında Yapılan Faaliyetler

\begin{tabular}{|l|l|}
\hline Okunan Kitap & Adedi \\
\hline Edebiyat & 30 \\
\hline
\end{tabular}




\begin{tabular}{|l|l|}
\hline Coğrafya & 15 \\
\hline Felsefe & 10 \\
\hline Müspet ve Tabii İlimler & 20 \\
\hline Dil & 15 \\
\hline Sosyal Bilimler & 25 \\
\hline Ar & 10 \\
\hline Tarih & 25 \\
\hline Sair Kitaplar & 40 \\
\hline Gazete ve Mecmua & 60 \\
\hline
\end{tabular}

Kaynak: B.C.A.,K.H. 1937 Y.F.R., 1937: 8.

$\mathrm{Bu}$ tabloda kütüphane ve yayın kolu tarafindan tutulan kayıtlarla bir yılın 2.altı ayı içinde okunan kitap çeşidi ve okuyucu adedinin kayıtlarını görmekteyiz. Burada okuyucu sayısının, gazete ve mecmua ile edebiyat ve tarih kitapları üzerinde yoğunlaştığı görülmektedir.

Tablo 2.16: Kütüphane ve Yayın Şubesinin 1941 Y1lı Faaliyetleri

\begin{tabular}{|l|l|l|l|}
\hline & Eser Sayıs1 & Okuyucu & Okuyucu Öğretmen \\
\hline Felsefe & 2 & 3 & - \\
\hline Din & 2 & 6 & - \\
\hline Sosyal Eserler & 7 & 7 & 5 \\
\hline Dil & - & - & - \\
\hline Nazarî İlimler & 6 & 7 & - \\
\hline Tatbikî İlimler & 2 & 4 & - \\
\hline Güzel Sanatlar & 7 & - & - \\
\hline Edebî Eserler & 44 & 12 & 7 \\
\hline Tarih ve Coğrafya & 10 & 15 & 7 \\
\hline Umumî Eserler & 570 & 62 & 7 \\
\hline
\end{tabular}

Kaynak: B.C.A., K.H. 1941 Y.F.R., 1941:1.

Tabloda kütüphane ve yayın şubesinin 1941 yılında ki kitap sayısı, kitap çeşidi ve okuyucu sayılarını görmek mümkündür. Ayrıca okuyucu öğretmenler için ayrı bir kaydın tutulduğu dikkat çekmektedir.

\subsection{Köycülük Şubesi ve Faaliyetleri}

Bu şube 19 Temmuz 1932 tarihinde kurulmuştur. Üye sayısı 224'tür. 1933 tarihli faaliyet raporuna göre yapılan faaliyetler şunlardır: 
1-Köylünün hükümetteki işlerinin takipten başlayarak 350 köylünün arzuhalleri yazılmıştır.

2-Halkevlerinde s1k sik verilen müsamere, konferans ve musiki toplantılarına köylülerin iştiraki ve halkevine bağlılıkları temin edilmiş, bu bağlamda firka kongresi sırasında gelen köylü murahhaslar ve bayramda şehirde bulunan bir çok köylü, halkevinde misafir edilmiştir.

3-Halkevlerindeki muhtelif şubelere bağlı üyeler, köy gezileri yaparak hastalar muayene edilmiş ve ilaçları temin edilmiştir.

1935 y1lı faaliyet raporuna göre köycülük şubesi faaliyetleri şu şekilde kaydedilmektedir:

1-Köylülerin şehirdeki işlerini yürütmek ve kolaylaştırmak için halkevi ve partinin bürosu daima açık bulundurulmuştur.

2-Gösterit ve sosyal yardım şubelerinden oluşan gruplar Emet'in Çavdarhisar, Simav'ın Değirmenciler, Yenice, Demirci, Gül, Naşa, Çöngüller; merkez Gümüş Nahiyesi'nin Hamalı, Okçu, Çivli, Bölcek, Köprüören; Gireği Nahiyesi'nin Aslanapa ve diğer köylerine gezi düzenlemiş, bu gezilerde 2500 köylü ile devrim konuları üzerinde konuşmalar yapılmıştır.

3-Cumhuriyetin 12. yılına kadar yapılan işler (devrimin kültür, vergi, inhisarlar, adliye, bayındırlık, millî mücadele ve dış işlerinde on iki yıllık muvaffakiyetlerini anlatan sunumlar) 10 konferans halinde anlatılmıştır.

4-320 dergi dağıtılmış, 160 hastaya bakılmış ve bir kilo kinin dağıtılmıştır.

5-Altıntaş Nahiye merkezinde, alanda yirmi köyden toplanan halkın önünde (Himmetinoğlu) gösteriti verilmiştir.

Tablo 2.17: Köycülük Şubesinin 1941 Y1lı Faaliyetleri

\begin{tabular}{|c|c|c|c|c|c|c|}
\hline \multirow{3}{*}{ 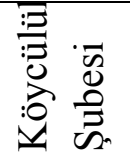 } & \multicolumn{2}{|c|}{ Komite } & \multicolumn{2}{|c|}{ Şube } & \multicolumn{2}{|c|}{ Köy Geziler } \\
\hline & Toplantı Sayıs & Katılan & Toplantı Sayıs & Katılan & Gezi Sayıs1 & Katılan \\
\hline & 8 & 40 & 3 & 150 & 5 & 4500 \\
\hline
\end{tabular}

Kaynak: B.C.A., K.H. 1935 Y.F.R.,1935: 9.

Tablo 2.18: 1941 Yılında Diğer Şubelerle İşbirliği Yaparak Gerçekleştirdiği Faaliyetler

\begin{tabular}{|l|l|l|}
\hline Gezilen Köy & Tarih & İş Birliği Yapılan Şube \\
\hline Ballıca & $01 / 08 / 1941-02 / 08 / 1941$ & Sosyal Yardım Şubesi \\
\hline Bozköy & $15 / 02 / 1941-17 / 02 / 1941$ & Spor Şubesi \\
\hline Dereköy & $02 / 10 / 1941-03 / 10 / 1941$ & Gösterit Şubesi \\
\hline Yatağan & $25 / 12 / 1941-25 / 12 / 1941$ & Kurslar Şubesi \\
\hline
\end{tabular}

Kaynak: B.C.A., K. H. 1941 Y. F.R. ,1941: 1 
$\mathrm{Bu}$ tabloda Köycülük şubesinin diğer şubelerle işbirliği yaparak gerçekleştirdiği faaliyetlere yer verilmiştir. 1941 yılı içerisinde yapılan bu faaliyetlere, her şubenin kendi faaliyet alanını köylere taşıması olarak bakılabilir. Örneğin Temsil şubesi hangi temsili sunuyorsa, bunu köye taşımış sosyal yardım şubesi de ilgi alanını köye yöneltmiştir. Bu sayede halkevleri köycülük şubesinin açılış amacı da olan; köylü- şehirli arasında ki bağı ve iletişimi kurma amacının da böylece sağlanmaya çalışıldığı düşünülebilir.

\section{Kütahya Halkevi Neşriyatı}

Kütahya Halkevi'nin süreli bir yayını bulunmamaktadır. Bu nedenle bu bölümde özellikle dil edebiyat ve tarih şubesi tarafından yayınlanan eserler ve halkevi tarafından gönderilen yerel basında çıkan yazılara yer verilmiştir. Neşriyat, kitap ve broşür olarak iki kategoride ele alınmış, içerik olarak bir değerlendirme yapılmıştır.

\section{o 3.1.Kitaplar}

Halkevi tarafından yayınlanan 4 kitap bulanmaktadır. Kitapların yazarları Mustafa Hakkı Yeşil ve Halil Kadri' dir. Halil Kadri Kütahya'nın kurucu halkevi başkanı olmasının yanında, vilayet matbaasının da sahibidir.(bkz.sh.5) Eserlerin hepsinin bu matbaada basılmış olması, bu konudaki özverili çalışmalarını gösterir. Aşağıda, halkevi tarafından yayınlanan kitaplar tanitılmaktadır:

\section{Halk Şairleri}

Kütahya Halkevi Dil, Tarih ve Edebiyat Şubesi'nin yayınladığı bir araştırma eseridir. Mustafa Hakkı Yeşil tarafından kaleme alınmıştır.1934 yılında yayınlanan bu araştırmada, Kütahya'nın kıdem itibarıyla en eski şairinden başlayarak günümüze kadar olan şairlerin hayatları ve eserleri üzerinde durulmuştur. Bu şairlerden ilki Aşık Sırrı'dır ve kıdem olarak Kütahya'nın en eski şairidir.

İkinci şair Aşık Şükrü olup Aşık Sırrı'nın muasırıdır. İsmi, M. Fuat Köprülü’nün "Türk Edebiyatında İlk Mutasavvıflar" adlı eserinde de geçmektedir. Üçüncü şair ise Pesendi'dir. Kütahya'nın iftihar edeceği bir şair olduğundan bahsedilmekte ve eserlerine yer verilmektedir. Sırasıyla, Aşı Hasan ve Son Aşıklar başlı̆̆ı altında diğer şairlerden de bahsedilmektedir (Yeşil, 1934).

\section{İktisadî Devletçiliğimiz}

1933 yılında Halil Kadri tarafından kaleme alınmıştır. Yazıda "İnsanların topluluk hallerinden bahseden sosyal bilgilerin temeli olan ve gün geçtikçe bütün sosyal grupların mihverini teşkil eden iktisat ilmi penceresinden, Türk İktisadî Devletçiliğinin "tahlil ve tetkiki” amaçlanmıştır (Kadri, 1933:1).

Yazının başında "İktisadi Devlet” sözünün ne demek olduğuna cevap bulmak için, iktisat ilminin tarihçesinden bahsedilmektedir. İktisat telakkisinin ve bu telakkinin tekâmülünün şeması çizilerek, iktisadın bir bilim olma yolunda kısa mazisi anlatılmaktadır. 
15. yüzyıldan 18. yüzyıla kadar adına merkantilizm denen aşırı müdahaleci ekonomik anlayış ve bunun tadil edilmiş hâli alan iktisadî hadiselere tabii nizamın hâkim olduğu kanaatlerinin noksan, yanlış ve indi hükümlere dayandığı ileri sürülmüş, ardından etkili olan serbest iktisadî sistemin doğuracağı dünya şöyle tasvir edilmiştir: "Bir yanda Himalaya heybetinde yığılan milyarların üstünde, milyarlık yığınlara yukarıdan ve istihfafla bakan birkaç zengin millet" (Kadri, 1933: 2-3).

Daha sonra 1. Dünya Savaşı'nda dünyanın hâlihazırdaki durumu tasvir edilmiştir. Müstemleke ve müstemlekeci olarak ikiye bölünmüş insanlar harp sonunda bu gidişatı kabul eden tarafın düşünme ve kalkınma kabiliyetleri azaltılıp yok edilirken, Türkiye haricinde hiç bir yerde harp sonunda bir silkinme ve yeniden dirilme hareketi görülmediği ifade edilmiştir. Türkiye, daha ilk başta müstakil devlet olma adına hiç taviz vermemiş ve bir vatan yaratmak için hiçbir milletin hayati şartlarına uymayan yeni ve kendine mahsus bir iktisadî anlayışı inkişaf ettirmiştir (Kadri, 1933: 2-3).

$\mathrm{Bu}$ yeni ekonomik anlayış "Dünün çürümüş idari telakkilerinden ayrı, günün ve bünyemizin ihtiyacına uygun bir iktisadi devlet" (Kadri, 1933: 7) olarak tanımlanmıştır. Yazara göre diğer sistemlerde sıfira indirilen devlet bu sistemde her şeydir. Daha sonraki kısımda devletçilik; istihsal, istihlak ve inkısam tasnifleri bakımından tahlil edilmiştir. Bunlar kısaca şöyledir: “ 1. İstihsalde devletçiyiz. Çünkü bugün için hammadde yetiştirip imal eder ve kendine yeter bir hale gelmek ve yarının ihracatçısı olmaya hazırlanmak için çalışmak gerekmektedir. 2. İstihlakte (tüketim) devletçidir. Çünkü yurt üstünde iş bölümü ve çalışma birliği yapan vatandaş kitlelerinin istihlak kabiliyetlerini arttırmak, iktisadî bir vecibe olduğu kadar, refahı arttırmak ve yaymak, inkılâbın millete vaat ettiği bir mükâfattır. 3. Servetin dağılışı bakımdan devletçiyiz Avrupa'nın tecrübe ettiği çürük köprüden, sınıf köprüsünden geçmek istemiyoruz. Sınıf tezadı yerine millet bütünlüğü ve kitle kaynaşması istiyoruz" (Kadri, 1933: 13). Eserde ayrıca 10 yıllık Cumhuriyet döneminde yapılan iktisadî işler anlatılmış, diğer sistemlerden fark1 ve üstünlüğü örnekleriyle açıklanmıştır (Kadri, 1933: 1213).

\section{Altıok (Cumhuriyetçiyiz, Milliyetçiyiz, Halkçıyız, Devletçiyiz, Laikiz, İnkılâpçıyız)}

Halil Kadri tarafından 1934 yılında kaleme alınmıştır. Eser şu şekilde başlar: "Fırka bayrağında aklarla gösterilen bu çok derin manalı sözlerin ne demek olduğunu hepimiz çok iyi biliriz. Fakat içimizde bu işi iyice kavrayamayanlar da bulunabilir. Bunun için ben burada birer birer bu sözleri anlatmaya çalışacağım” (Kadri, 1934: 1). Buradan da anlaşılacağı gibi eserde bazı kavramların ayrı ayrı tafsilatı yapılmıştır. Yalnız bu yapılırken tamamen halkın anlayacağı bir dilin kullanılmasına dikkat edilmektedir. Cumhuriyet anlatılırken herkesin kolaylıkla anlayacağı bir üslup kullanılmış, zıttıyla karşılaştırma yapılarak halka "Şimdi bu mu iyi, öteki mi ?’diye sorulmuştur. Eserde: Cumhuriyetin halka seçme ve seçilme hakkı tanıdığı anlatılırken, Osmanlı dönemine de eleştiriler getirilir. Bu kısım şu şekildedir: "Bir Osmanoğulları vardı. Bizim köydeki Kara Hasanoğulları, Deli Tomrukoğulları gibi haşa! Onlar gibi de değil... Çünkü bizim köydeki Kara Osmanoğulları, Deli Tomrukoğulları öz be öz bizdendir, Türk’tür. Bu Osmanoğulları öyle de değildi. Her çeşit milletten kız almışlar, 
içlerine Maskat karışmış, Rum karışmış, Yahudi, Fransız, İngiliz hepsi var. Ha! İşte bu Osmanoğulları denen sülaleden gelen çocuklar mutlaka bize baş olacak, padişah olacak, hâşâ Allah'ın gölgesiyim diyecek biz karşısında el pençe duracağız” (Kadri, 1934: 2). Bu şekilde saltanatın ne demek olduğu anlatıldıktan sonra Cumhuriyetin üstünlükleri üzerinde durulmuştur.

Yukarıda anlatılanlar gibi diğer tüm ilkeler aynı şekilde karşılaştırmalı olarak açıklanmıştır. Osmanlı milliyetçiliği, daha doğrusu Osmanlı Devleti'nin milliyetçi olmadığı eleştirilerek, Türk milliyetçiliği kavramının Cumhuriyetle kazanılan bir kavram olduğu belirtilmiş, eskiden Türk olduğumuzun unutturulduğu ifade edilmiştir. Sırasıyla Halkçılık, Devletçilik, Laiklik ve İnkılâpçılık kavramları, halkın anlayacağı tarzda, örnekleri kendi içlerinden ve yaşanan olaylardan verilerek daha iyi anlaşılması amaçlanmıştır.

\section{Ülkü Yolunda Kütahya Halkevi}

24 Haziran 1933 yılında yayınlanan eserin müellifi belli değildir. 24 Haziran 1932 de kurulan Kütahya Halkevi'nin 1. yıldönümü münasebetiyle yayınlanan eser Kütahya Halkevi hakkında önemli bilgiler içermektedir. Kütahya Halkevi’nin kuruluşu, teşkilatları, 1 yıl içindeki faaliyetleri ve idarî heyetinin teşkilat başkanları ve azalarıyla ilgili olarak ayrıntılı malumatın verildiği eser, fotoğraflarla zenginleştirilmiştir.

Eserin önsöz kısmında Kütahya Halkevi'nin kuruluşu anlatılmaktadır. Kuruluşta hazır bulunan zatlar ve açılış merasimi tasvir edilmiş, daha sonra halkevinin kurulu şubelerine geçilmiştir. Sırasıyla dil, tarih ve edebiyat, güzel sanatlar, temsil, spor şubesi, içtimai yardım, halk dershaneleri ve kurslar, kütüphane ve neşriyat, köycülük şubelerinin, kuruluş zamanı ve aza sayıları verilerek bir yıl içindeki faaliyetleri bir rapor halinde anlatılmıştır (Ü.Y.K.H,1933: 3-4). İdare heyeti kısmında başkan ve azalar, şubelerin başkan ve azaları, meslekleriyle beraber bir tablo şeklinde verilmiştir.

\section{O 3.2.Broşürler}

Halkevi tarafından yayınlanan diğer eserlerdir. Bu eserler halkı bilinçlendirme adına el kitapçıkları şeklinde hazırlanmıştır. Sağlık, sosyal ve kültürel konularda yayınlanan bu eserler halka ücretsiz dağıtılmıştır.

\section{Kütahya'da Cumhuriyetin On Yılı}

Cumhuriyetin 10. yıl dönümü adına 1933 yılında Halil Kadri tarafından Kütahya'da yazılmıştır. Cumhuriyetin 1923 yılında kurulmasından, 1933 yılına kadar tüm yurtta görülen hızlı değişim Kütahya alt başlığında ortaya konulmuştur. "İnkılâptan Önce” başlığı altında "Kütahya Vilayeti Cumhuriyeti müjdeleyen 101 atım topun ufuklarda çınladığ gün şu vaziyette idi" ifadeleriyle köy, şehir ve kasabalardaki durum anlatılmaktadır. "Vilayetin Maarifi” başlığı altında o günkü eğitim müesseseleri sayılarıyla verilmiş, eğitim gören ve 
eğitimi veren insan sayıları belirtilmiştir. Rakamlara göre vilayet nüfusunun okuryazar oranı $\% 2$ 'dir. $\mathrm{Bu}$ açıklamalardan sonra, Cumhuriyetin 10. yılında gelinen nokta rakamlarla anlatılmıştır. Buna göre 10. yılda okur-yazar oranı kadınlarda \%7, erkeklerde ise \%18'e ulaşı1lmıştır (Kadri, 1933:12).

“İktisadi Bakımdan” başlıklı bölümünde 10 yıl içinde yaşanan değişmeler anlatılmış, aşar vergisinin kaldırılmasının doğurduğu olumlu sonuçlar, yine hayvan sayılarındaki artışla verilmiştir. Cumhuriyetle beraber ziraî alanda pancarı ekiminin kazanımları anlatılmıştır. Bunun yanında nafia işleri, maden, belediye hizmetleri, sağlık işleri ve içtimai tekâmül alanlarında hızlı değişim, açıklayıcı bir şekilde eskiyle karşılaştırılmalı olarak verilmiş, ayrıca halkevlerine de değinilmiştir (Kadri, 1933: 13).

\section{Köycünün Defteri}

Kütahya Halkevi Köycülük Şubesi tarafından 1934 yılında hazırlanmıştır. Bilgi edinme amaçlı olarak hazırlanan ve halkodalarına gönderilen bir defterdir. Köycülük şubesinde aktif rol oynayan ve faaliyet gösterenlere "köycü” denildiğinden bahsedilmekte, defterin kapağında ise tetkik edilen köy hakkında belli açıklamalar bulunmaktadır. Defterin köyleri tanıma ve tanıtmaya yönelik olduğu, doldurulması için boş bırakılan yerlerden anlaşılmaktadır. Defter çok ayrıntılı olarak hazırlanmıştır. Köyün fiziki yapısından, sosyal yapısına, adetlerine, batıl inançlarına kadar, kıyafetleri, nazar telakkileri, ekonomisi hatta evlerde genelde hangi kitapların olduğu hakkında bilgi verilmiştir. Bu konular arasında köylerde halkodalarının çalışmaları da vardır. Araştırmalarımıza rağmen bu defterin doldurulmuş bir örneğinde ulaşamadık.

\section{Karasinek Zararları ve Korunma Çareleri}

Dr. Nazif Seçkin tarafından 1935 yılında yazılmıştır. Eser anlaşıldığı kadarıyla sağlık kurumlarının hastalıkla mücadeleye karşı açtı̆̆ı savaşa, halkı da dâhil etmek için bilgilendirme amacı taşımaktadır. "Karasinek" başlığı altında bu hayvanın tanımı, neden olduğu hastalıklar, mikrobu nasıl taşıdığına kadar ayrıntılı bir açıklama yapılmıştır. Daha sonra alt başlıklar halinde karasineklerden kurtulmak için yurttaşlara düşen görevler, maddelenmiş, yapılacak işler, hayvanları koruma yolu, tafsilatlarıyla anlatılmıştır ( Seçkin, 1935: 5).

Eserde şehir hayatından daha çok, köy hayatına yönelik örneklere yer verilmesi ve eserin konusunun daha çok köylüleri ilgilendiriyor olması, köycülük kolu tarafından yayınlandığı ihtimalini kuvvetlendirmektedir. Hitabı yani tamamen halkın anlayacağı tarzda ve dilde yazılmış olması, el broşürü şeklinde köylüye dağıtıldığını da düşündürmektedir. Çünkü tür bilgilendirme ve broşürlerinin köylülere dağıtılma faaliyetleri, bizzat faaliyet raporlarında görülmektedir. Nitekim 1935 yılında Kütahya Halkevi Köycülük Şubesi tarafından köylülere 320 broşür ve kinin dağıtılmıştır (CHP H.H.,1932-1942:21). 


\section{Türkçe İçin Bir Konferans}

İshak Refet tarafından 1933 yılında kaleme alınmıştır. Yazar esere iki kitabı tanıtarak başlar. Bunlardan birincisi "Divan-1 Lügatit Türk", diğeri "Mikyasül Lisanül-Kıstasül Beyan"dır. Birincisini Kaşgarlı Mahmut diğerini de Kütahyalı Abdurrahman Efendi'nin kaleme aldığı bu eserler temel alınarak yazar dilimizi yükseltmeye düzeltmeye ve zenginleştirmeye engel olan iki düşüncenin yanlışlı̆ğnı ispat etmeye çalışılmıştır. Bu iki yanlış düşünce şunlardır: 1.Çağatayca, Uygurca gibi eski Türk lehçelerinin Türkçeden ayrıymış gibi düşünülmesi 2. Türk Dili’nin Züğürtlüğü (Refet: 1932: 4).

Kitapta Kaşgarlı Mahmut ve Kütahyalı Abdurrahman Efendi'nin yanlışları, başta ismi belirtilen eserlerdeki karşılaştırmalarla çürütülmeye çalışılmıştır. Bugün kullandığımız Türkçenin eski Türkçenin ilerlemiş bir uzantısından başka bir şey olmadığı, yazı dilimize geçmeyen bir takım sözleri, Anadolu'da kullanılan şekliyle karşılaştırılarak Çağataycının ve Uygurcanın ne olduğu anlatılmaya çalışılmış, Türkçenin züğürt olmadığ çıkarılmaya çalışılmıştır (Refet,1932:5). Ayrıca eserde Osmanlı Türkçesi’ne eleştiri yapılmaktadır. Bu kısım şöyledir: “Osmanlı Türkiye'si ne kadar Türklerin değil idi ise, Osmanlı Türkçesi de o kadar ve öylece Türklerin öz malı değildir. Osmanlı Türkçesi büyük bir düğün evi gibiydi. Ev sahibi olan Türkler, Türk olmayanları ağırlamaya, doyurmaya, esirgemeye, korumaya, uğraştırılırlardı... Biraz dinlenmek sıraları gelince de yabancılar baş bucağa minderlere koltuklara yerleşirler, ev sahibi olan Türkler ise yine eşik başında kalırdı. Osmanlılıktan kalma bu Batı Çağataycısında da Türkçe hep aşağılık, kötü işlere verilmek istenmiştir. Herhangi bir sözün Türkçesini söylemek kabalık, Arapçasını veyahut Farsçasını söylemek incelik sayılmıştır... Cumhuriyet Türkiye'si Türklerindir, Türkiye'nin dili Türkçedir. Türkçe yazılır, Türkçe konuşulur. Zaten yeni yazımız güzel Türkçemizde can çekişen Arapça, acemce sözlerin mezarı olmuştur. Bunların ölülerine ağlamak düne bağl1lıktan başa bir şey değildir" ( Refet, 1932: 5).

\section{Kütahya Mesireleri}

Kütahya Halkevi'nde başkanlık da yapmış olan, şehrin ileri gelenlerinden Vilayet Matbaası müdürü Halil Kadri'nin kaleme aldığı bu eser, Kütahya'nın gezme, oyun ve türkü geleneğini kayıt altına almıştır. Eserde Kütahya şu şekilde tasvir edilir: "Yerlice eteklerinde genişçe sulak ve yemyeşil bir yayla üzerinde kurulmuş olan Kütahya şehri, mutedil ve latif havası, zengin tabiatı bol akarsuları ve çevresindeki çam koruları kaplıcalarıyla, bahar ve yaz mevsimlerinde en cazip yerlerden biridir. Şehri kuzeyinden kucaklayan tepelerin koynundan fışkırıp yayılan berrak ve soğuk sulardan başka önündeki düz ve yeşil alanda akan Felent ve Porsuk çaylarının vücuda getirdiği köme köme ağaçlıklar, reçine kokulu esinleri yumuşak teması ile salınıp bulanarak yazın sıcaktan bunalanları serin gölgeliklere çağırır" (Kadri,1937:1). Eserde Kütahya’nın mesire yerlerinin ayrı ayrı adları verilmiştir. Bu mesire yerlerinin hepsinin eskiden beri süre gelen belli gezme günlerinin olduğu, unutulmaya yüz tutmuş hususi şarkıları, sportif ritmik oyunları, güzel türküleri belirtilerek, özel menkıbeleri 
tamamen unutulmadan kayıt altına alınmak istenmiştir. Mesirelere ait bu eski adetler, efsaneler ve halk oyunları yaşayan insanlardan toplanmış, sadeliğinin ve orijinalliğinin bozulmamasına dikkat edilmiştir ( Kadri,1937: 6-8).

\section{Devrim Andıcı}

Eserin kapağında: "Devrimin önemli hadiselerinin bir özetini toplayan bu andıç, söyleyen ve okuyan üyelere bir kolaylık olsun diye çıkarılmıştır” (Kadri, 1936: 2) denilmektedir. 1936 yılında Halil Kadri tarafından yazılan eserde, Atatürk'ün Anadolu'ya ayak bastığı günden beri yapılan büyük işler kronolojik olarak sıralanmıştır. İstanbul'un işgalden kurtulmasından sonra yapılan inkılâplar, Meclisin toplanma tarihleri, demir yolu inşaatları, karayolları hatlarının başlaması ve tamamlanması, belli başlı kanunların kabul tarihleri, CHP'nin kongreleri, fabrikaların açılış tarihleri gibi konular andıçta yer almıştır (Kadri, 1936: 3-4).

\section{SONUÇ VE DEĞERLENDİRME}

Gerek şehir, gerekse kırsal kesimlerde yaşayan vatandaşlar arasında Türk kültürünü yaymak, Türk inkılâbını kökleştirmek, millî birlik ve beraberliği sağlamak amacıyla kurulan halkevleri, yurdumuzun diğer şehirlerinde olduğu gibi Kütahya'nın da kültürel hayatına bir dönem damgasını vurmuştur. 24 Haziran 1932'de açılan Kütahya Halkevi'nin; dil, tarih ve edebiyat, güzel sanatlar, spor, temsil, sosyal yardım, halk dershaneleri ve kurslar, kütüphane ve yayın, köycülük şubeleriyle, halkevlerinin kapatıldığı 1951 yılına kadar faaliyetlerini sürdürdügü anlaşılmaktadır. Özelikle tiyatro, konser, konferans gibi halkın yoğun katılım gösterdiği faaliyetler, kültürel gelişimin önemli etkenlerini oluşturmaktadır. Halkın çoğu, ilk defa halkevi çatısında tiyatro, sinema, konser gibi kavramlarla tanışmış ve bu faaliyetlere dâhil olma imkânı elde etmiştir. Öyle ki bu faaliyetlerle köylere kadar gidilerek, buralarda yaşayan vatandaşların aydınlatılması ve hayat şartlarının iyileştirilmesi yönünde gayret sarf edilmiştir. Kütahya Halkevi'nin kente olan olan katkısı çok yönlüdür. Aktif olan her bir şubesinin yaptığı faaliyet alanları içinde ilk önce halkın katılımı esas alınmış, halka dönük ve halk için bir çalışma alanı belirlenmiştir. Bu yönde merkezden geri dönüşlere bakıldığında halkın katılımının sağlandığı oranda halkevleri başarılı sayılmıştır.

Kütahya Halkevi'nin faal olan şubeleri içinde halk dershaneleri ve kurslar şubesi halkevinin halka en yakın olduğu yerdi. Kursiyerlerle halkevi idarî heyetinin bir arada olduğu bu şube verimli çalışmalar yürütmüş, birçok insan bu şube faaliyetlerinden yararlanmıştır. Daha sonraları faaliyete geçecek olan halk eğitim merkezlerinin temellerinin bu şubeyle atıldı̆̆ söylenebilir. Halkevleriyle girişilen eğitim seferberliği içinde okuma yazma kurslarının da yeri önemlidir. Öyleki bu faaliyetle Kütahya'da özellikle eğitim kurumlarının dışında kalan yetişkin ve eğitim alamayan gençlerin okuma yazma öğrenmesi sağlanmıştır.

Diğer taraftan kültürel veri toplama faaliyetini gerçekleştiren dil edebiyat ve tarih şubesinin çalışmaları Kütahya açısından önemli sonuçlar doğurmuştur. Bu sayede unutulmaya 
yüz tutmuş söylemler ve geleneklerin tekrar canlanması sağlanmış, yayınlanan bir eserle de çalışmalar kalıcı hale getirilmiştir. "Kütahya Mesireleri" adlı bu eser unutulan mesire adetlerini, türküler ve manileri kayıt altına alınmıştır.

Kütahya yerel basınında çıkan haberler Halkevi faaliyetlerini duyuru tarzındadır. Halkın faaliyetlere olan yoğun ilgisini gösteren veriler özellikle halka yönelik organizasyonlara katılım sayılarıdır. Temsil, sinema, şölen ve bayram gibi halkevi faaliyetlerine, şehirde çok sayıda katılım olduğu görülmektedir. Halkevi faaliyet raporları esas alınarak hazırlanan bu çalışma ile Kütahya'nın 1930'lu yıllardaki kültürel hayatının aydınlatılmasına önemli bir katkı sağlanmıştır.

Kütahya Halkevi Anadolu'nun birçok yerinde yakın -uzak faaliyet gösteren halkevleri içindeki yeri bakımından değerlendirildiğinde eldeki verilere göre vasat bir performans sergilediği görülmektedir. Özellikle birçok halkevinde rastlayabileceğimiz süreli yayın, fotoğraf albümleri, "Halkevinden Haberler" sayfasıyla yerel gazetelerde halkevleri haberlerine pek rastlanmamaktadır. , Eldeki verilere göre Kütahya Halkevi faaliyetlerinin bu ile bağlı bazı ilçelere göre de daha yavaş seyrettiğini söylemek mümkündür. Nitekim arşiv belgelerinde Kütahya merkez halkevinden çok, o dönem Kütahya'nın ilçeleri olan Uşak Halkevi'nin adı daha çok geçmekte, Tavşanlı Halkevi haberlerine halkevlerinin merkez yayını olan Ülkü Dergisi’nde sıkça rastlanmaktadır. Ayrıca her iki halkevinin süreli yayını olmasına rağmen, Kütahya Halkevi’nin süreli bir yayını yoktur. Süreli yayın yerine; çoğunluğu tek bir ismin kaleme aldığı halkevi broşürleri vardır. Kütahya'nın tarihî ve kültürel zenginliklerine 1şık tutan bu eserler, Kütahya'da Cumhuriyetin ilk yıllarını resmetmesi bakımından oldukça önemlidir.

\section{REFERENCES}

\section{Arşiv Belgeleri}

- Başbakanlık Cumhuriyet Arşivi

- B.C.A.1933 Y1l F.R.

- B.C.A, K.H 1935 Y1lı Ç.R.Ö.

- B.C.A, K.H 1937 Y1lı Ç.R.Ö.

- B.C.A., Sicil Sureti 30/11/1939.

- B.C.A, Sicil Sureti $15 / 07 / 1944$.

- B.C.A., K.H 1935 Yı1ı Ç.R.Ö, No1208.

- B.C.A., K.H 1937 Yılı Ç.R.Ö, No:989.829.1.

- B.C.A., K. H. 1941 Yilı F. R.

- CHP, Halkevleri, 1940.

- CHP 1935, 103 Halkevi Geçen Yıllarda Nasıl Çalıştı, s. 44.

- CHP, Halkevleri ve Halkodaları 1932-1942.

- CHP, 1948, 16.Yıldönümünde Halkevleri ve Halkodaları,Ulus Basımevi,Ankara.

- CHP, Halkevleri Öğreneği,1938.

- CHP, Halkevleri Talimatnamesi,1932.

- CHP., Halkevleri Tüzüğü,1936.

- CHP Genel Sekreterliği, 103 Halkevi Geçen Yıllarda Nasıl Çalıştı? 1932-1935.

- CHP. H.B.A. 14.06.1941 Tarihli 8.361135 Sayılı Yazı. 
- CHP. H.B.A:1942, 8-52610 Say1l1 Yazı.

- CHP. H.B.A:1942, 6/7/1942,6/7/1946,19/8/1946 Tarihli Yazı.

- K. H.1935 yili F.R.

- K. H.1937 Y1lı 2.Altı Aylık F. R.

\section{DIĞER KAYNAKLAR}

- AKYOL, Yaşar, (1993), “İzmir Halkevi (1932-1951)”, Dokuz Eylül Üniversitesi, Sosyal Bilimler Enstitüsü, Yüksek Lisans Tezi, İzmir.

- ANDICI, Devrim, (1935), Kütahya Halkevi, Kütahya Basımevi, Kütahya.

- Atatürk'ün Doğumunu 100.Yılına Armağan, (1982), “Kütahya”, Kütahya Belediyesi Yayınları, İstanbul.

- CHP, (1932), Halkevleri ve Halkodaları, Ulus Yayınevi, Ankara.

- Çeçen, Anıl, (1990), Halkevleri, Gündoğan Yayınları, Ankara.

- $\quad$ ERGÜN, Mustafa, (1982), Atatürk Devri Türk Eğitimi, AÜDTCF Yayınları, Ankara.

- güz, Nurettin, (1995), Halkevleri Dergileri(1932-1950), Kariyer Matbaacillk, Ankara.

- Halk Şairleri, Kütahya Halkevi Yayınları, Kütahya Vilayet Basımevi, Kütahya.

- Halkevleri, (1932-1935), 103 Halkevi Gecen Yıllarda Nasıl Çalıştı, Ulus Yayınevi, Ankara.

- KADRİ, Halil, (1933), İktisadi Devletçiliğimiz, Kütahya Halkevi Yayınları, Vilayet Basımevi, Kütahya.

- KADRİ, Halil, (1934), Cumhuriyetçiyiz, İnkılapçıyız, Laikiz, Devletçiyiz, Halkçıyız, Milliyetçiyiz, Kütahya Halkevi Yayınları, Vilayet Basımevi, Kütahya.

- KADRİ, Halil, (1937), Kütahya Mesireleri, Kütahya Halkevi Yayınları, Vilayet Basımevi, Kütahya.

- Karaömerlioğlu, Asım, (2006), Orada Bir Köy Var Uzakta, İletişim Yayınevi, 1.Baskı, İstanbul.

- KARPAT, Kemal, H., (1968), Türk Demokrasi Tarihi, Alfa Yayıncılık, İstanbul.

- Kılınç, Eşref, (1968), Türkiye'de Halk Eğitimi, Milli Eğitim Basımevi, Ankara.

- Köycünün Defteri, (1935), Kütahya Halkevi Neşriyatı, Vilayet Basımevi, Kütahya.

- Kütahya Vilayet Gazetesi, "Bayramlaşma”, 25 Mart 1934.

- Kütahya Vilayet Gazetesi, "Halkevi Müsamereleri”, Sayı.750, 30 Birinci Teşriin1942.

- Kütahya Vilayet Gazetesi, "Halkevleri Müfettişi Vilayetimiz Evini Ziyaret Etti”, Say1 591,Teşrinievvel 1939.

- Kütahya Vilayet Gazetesi, "Halkevlerinde Müsamere”, 11 Şubat1934.

- Kütahya'da Cumhuriyetin 10. Yılı, Kütahya Halkevi Yayınları, Vilayet Basımevi, Kütahya.

- Oral, Mustafa, (2006), Halkevlerinin Toplumsal ve Kültürel İşlevleri, A.Ü. Yayınları, Antalya.

- Ölçen, nejat, (1942), Halkevlerinin Yok Edilişi, Ulus Yayınevi, Ankara.

- özsarı, Mustafa, (2002), Halkevlerinin Açılma Sebepleri, Hece Yayınları, Ankara.

- REFET, İshak, (1932), "Türkiye İçin Bir Konferans Kütahya Halkevine Armağan”, Kütahya Halkevi Yayınları, Vilayet Basımevi, Kütahya.

- SEÇKIN, Nazif, (1935), Karasinek Zararları ve Korunma Yolları, Vilayet Basımevi, Kütahya.

- Ülkü Yolunda Kütahya Halkevi (1933), Vilayet Basımevi, Kütahya. 
- ÜLKÜ, Necip Ali, (1933), "Halkevleri”, Ankara.

- YEŞiL, Hakk1, Mustafa, (1934), Halk Şairleri, Kütahya Halkevi Neşriyatı, Kütahya.

- Yeşilkaya, Neşe, Gürallar, (1999), Halkevleri: İdeoloji ve Mimarlık, İletişim Yayınevi, 1.Bask1, İstanbul. 